\title{
A new era of cancer treatment: carbon nanotubes as drug delivery tools
}

This article was published in the following Dove Press journal:

International Journal of Nanomedicine

2I November 20II

Number of times this article has been viewed

\section{Seyed Yazdan Madani' \\ Naghmeh Naderi' \\ Oshani Dissanayake' \\ Aaron Tan' \\ Alexander M Seifalian ${ }^{1,2}$ \\ 'Centre for Nanotechnology and Regenerative Medicine, Division of Surgery and Interventional Sciences, University College London, UK; ${ }^{2}$ Royal Free Hampstead NHS Trust Hospital, London, UK}

\begin{abstract}
Cancer is a generic term that encompasses a group of diseases characterized by an uncontrolled proliferation of cells. There are over 200 different types of cancer, each of which gains its nomenclature according to the type of tissue the cell originates in. Many patients who succumb to cancer do not die as a result of the primary tumor, but because of the systemic effects of metastases on other regions away from the original site. One of the aims of cancer therapy is to prevent the metastatic process as early as possible. There are currently many therapies in clinical use, and recent advances in biotechnology lend credence to the potential of nanotechnology in the fight against cancer. Nanomaterials such as carbon nanotubes (CNTs), quantum dots, and dendrimers have unique properties that can be exploited for diagnostic purposes, thermal ablation, and drug delivery in cancer. CNTs are tubular materials with nanometer-sized diameters and axial symmetry, giving them unique properties that can be exploited in the diagnosis and treatment of cancer. In addition, CNTs have the potential to deliver drugs directly to targeted cells and tissues. Alongside the rapid advances in the development of nanotechnology-based materials, elucidating the toxicity of nanoparticles is also imperative. Hence, in this review, we seek to explore the biomedical applications of CNTs, with particular emphasis on their use as therapeutic platforms in oncology.
\end{abstract}

Keywords: carbon nanotubes, cancer, photothermal therapy, drug delivery, cytotoxicity, near infrared

\section{Introduction}

In the UK there are more than 293,000 newly diagnosed cases of cancer each year. More than one in three people will develop some form of cancer in their lifetime. ${ }^{1}$ The most commonly diagnosed cancers among people in the UK are cancer of the breast and lung and colorectal cancer. Lung and colorectal cancer are the most common causes of death from cancer. The current arsenal against cancer includes surgical resection, chemotherapy, radiotherapy, or a combination of these three modalities. ${ }^{2}$ In spite of improvements in the efficiency of treatments over the last few decades, the majority of conventional chemotherapeutic formulations (tablet, capsule, injection) pose multiple problems, such as systemic toxicity and a destructive "bystander" effect to neighboring cells. In addition, there are risks of nephrotoxicity, neurotoxicity, vascular toxicity, infertility, and thromboembolic complications, as well as the more commonly anticipated side effects, such as hair loss, nausea, and myocardial infarction.

Other problems incurred with conventional chemotherapy include the inability of drugs to access tumor sites specifically, and difficulty in clinical administration of drugs. ${ }^{3}$ For these reasons, the two main areas that have been addressed by different
Correspondence: Alexander M Seifalian Centre for Nanotechnology and Regenerative Medicine, University College London, London, UK

Tel +44207830290I

Email a.seifalian@ucl.ac.uk 
research groups are destruction of cancer cells with minimum harm to normal body tissue ${ }^{4}$ and delivery of high doses of drug molecules to tumor sites for maximum treatment efficacy. ${ }^{5}$ Due to the advances in synthetic chemistry over the last few years, different biological nanomaterials ${ }^{6}$ have been developed, which can be used for a variety of biological therapies, such as drug delivery, cancer diagnosis, treatment, and imaging. This group of nanomaterials includes quantum dots, ${ }^{7}$ dendrimers, carbon nanotubes (CNTs), gold and silver nanoparticles, liposomes, ${ }^{8}$ and micelles. ${ }^{9}$

CNTs have attracted tremendous attention due to their unique properties as one of the most promising nanomaterials for a variety of biomedical applications. ${ }^{10}$ In comparison with other nanomaterials, CNTs appear to be more dynamic in their biological application. For example, the main application of quantum dots is cancer cell imaging alone, whilst CNTs have the potential to be used not only in imaging but also for drug delivery and thermal ablation. ${ }^{2}$ Application of CNTs for the delivery of drugs to their site of action has become one of the main areas of interest for different research groups. This is mainly because of the characteristics of these materials, including their unique chemical, physical, and biological properties, nanoneedle shape, hollow monolithic structure, and their ability to obtain the desired functional groups on their outer layers. ${ }^{10}$ The shape of the CNT would allow these materials to enter the cell via different methods, such as passive diffusion across the lipid bilayer, or endocytosis, whereby the CNT attaches to the surface of the cell and is subsequently engulfed by the cell membrane. ${ }^{10,11}$ The hollow monolithic structure of CNTs and their ability to bind desired functional groups make CNTs promising drug carriers. They can be functionalized to be more water-soluble and serum-stable, with low toxicity at the cellular level..$^{10,12}$

There has been great interest in the mechanism of cellular uptake of CNTs in the literature, and different methods have been investigated to elucidate this concept. Labeling CNTs with fluorescent materials, such as quantum dots, enables researchers to track the movement of CNTs. ${ }^{13}$ Additionally, detection of CNTs by nonlabeling methods such as transmission electronic microscopy or atomic force microscopy has also been undertaken. ${ }^{10,14}$ The advantage of using atomic force microscopy is that it can operate in liquid form, allowing for measurement under near physiological conditions. ${ }^{11}$ Figure 1 illustrates the presence of CNTs inside the cell by the aid of transmission electron microscopy.$^{15}$ Labeling CNTs with fluorescent agents and adding CNT-fluorescent agents to the cells has shown that CNTs are easily internalized into the nucleus. ${ }^{16,17}$ Kam et al reacted streptavidin-fluorescein

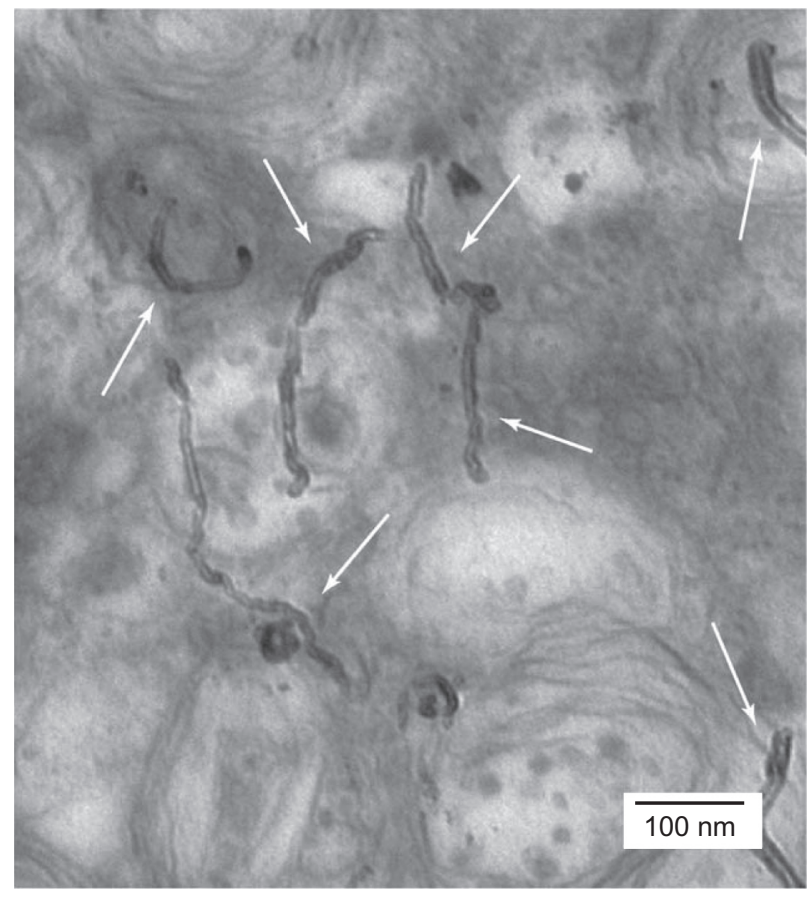

Figure I Transmission electronic microscopic imaging showing HeLa cells treated with functionalized multiwalled carbon nanotubes. As the white arrows illustrate, the functionalized carbon nanotubes were distributed into the cytoplasm. ${ }^{15}$ Reprinted from Curr Opin Chem Biol, Vol. 9, Bianco et al, Applications of carbon nanotubes in drug delivery, pp. 674-679, Copyright (2005), with permission from Elsevier.

isothiocyanate with CNTs and added this complex to HeLa cells. Their observation by confocal microscopy showed the presence of streptavidin-CNT inside the cells. ${ }^{18}$

The method of attaching biological molecules to CNTs can vary. Drugs and biological molecules can either attach to the surface through functional groups or be loaded inside the CNTs. These methods are also called wrapping or filling modes of binding, respectively. ${ }^{19}$ Another consideration whilst functionalizing CNTs is to improve their hydrophilicity. This can be achieved by reacting CNTs with strong acid, resulting in the formation of a carboxylic group on their surface, which increases their dispersability in aqueous solutions. Alternatively, hydrophilic materials can be covalently or noncovalently attached to the surface of CNTs ${ }^{15,20}$ Polyethylene glycol (PEG) coating can improve the hydrophilicity, biocompatibility, and immunogenicity of CNTs. ${ }^{9,21}$ The aim of this review is to consider the biomedical applications of CNTs in drug delivery and targeting of cancer cells for thermal ablation. Furthermore, we seek to address issues related to possible toxic effects of CNTs.

\section{Carbon nanotubes}

CNTs are well ordered, hollow, carbon graphitic nanomaterials with a range of properties. Some of these are a high aspect ratio, high surface area, and ultralight weight. ${ }^{10}$ 
Typically, CNTs are classified as single-walled (SWCNT) or multiwalled (MWCNT). SWCNTs consist of a single cylindrical carbon layer with a diameter in the range of $0.4-2 \mathrm{~nm},{ }^{22}$ depending on the temperature at which they have been synthesized. It has been observed that a higher growth temperature gives a larger diameter. In contrast, MWCNTs are usually made from several cylindrical carbon layers with diameters in the range of $1-3 \mathrm{~nm}$ for the inner tubes and $2-100 \mathrm{~nm}$ for the outer tubes. ${ }^{23}$

In terms of the structure of the two types of CNTs, it has been proposed that the basic carbon arrangement of SWCNTs is different from that of MWCNTs. The structure of SWCNTs is organized according to armchair, zigzag, chiral, or helical arrangements. On the other hand, the structure of MWCNTs can be divided into two types according to the arrangements of the graphite sheets. One is a "Russian-doll"-like structure where the graphite sheets are arranged in concentric layers and the other is a parchment-like model where the single sheet of graphite is rolled around itself. ${ }^{24}$

CNTs can be synthesized by heating carbon black and graphite in a controlled flame environment. The major problem using this method is the irregularity in shape, size, mechanical strength, quality, and purity of the CNTs obtained. ${ }^{12}$ To avoid these problems, techniques such as electric arc discharge, laser ablation, or catalytic decomposition of hydrocarbons have been suggested. Depending on the type of synthesis, different types of CNTs with different properties can be synthesized..$^{22,25}$ The appropriate fabrication technique can be utilized according to the intended application of the CNTs. For example, if CNTs are required for electric transport, SWCNTs should be used rather than MWCNTs. This is because SWCNTs can be either semiconducting or metallic whereas MWCNTs are semiconducting. ${ }^{22}$ In drug delivery, SWCNTs are known to be more efficient than MWCNTs. This is due to the one-dimensional structure of the SWCNT and efficient drug-loading capacity because of its ultrahigh surface area. ${ }^{26}$ It has been shown that a SWCNT-anticancer drug complex has a much longer blood circulation time than the anticancer drug on its own, which can lead to more prolonged and sustained uptake of the drug by tumor cells via the enhanced permeability and retention effect. ${ }^{5}$ Various reports have suggested that once the functionalized SWCNT releases the drug into a specific area, it is gradually excreted from the body via the biliary pathway and finally in the feces. ${ }^{27}$ This suggests that SWCNTs are suitable candidates for drug delivery and a promising nanoplatform for future cancer therapeutics.

SWCNTs can also be used for imaging. Single-molecule fluorescence spectroscopy and Raman spectroscopy techniques can be used to analyze the fluorescence and structural properties of SWCNTs. Results show that, unlike most single molecules or semiconductor nanoparticles, there are no spectral or intensity fluctuations for SCWNTs. Fluorescence spectra from individual nanotubes with identical structures have different emission energies and line widths that likely arise from defects in the local environment. $^{28}$

MWCNTs are known to be more useful than SWCNTs for thermal treatment of cancer. ${ }^{29}$ This is due to the fact that the MWCNTs release substantial vibrational energy after exposure to near infrared light. The release of this energy within a tissue produces localized heating, which can be exploited to destroy cancer cells. Because MWCNTs have more available electrons per particle and also contain more metallic tubes than SWCNTs, they tend to absorb near infrared radiation at a faster rate.

\section{CNT functionalization techniques}

Despite the advantages of CNTs, there are limitations to their biomedical use. Purification of CNTs is still tedious. CNTs that are commercially available are severely contaminated with metal catalysts and amorphous carbons, and are known to be generally insoluble and not biocompatible. In order to make these materials less toxic and more biocompatible, a number of procedures have been designed to attach appropriate molecules to the CNT surface, known as functionaliza$\operatorname{tion}^{30}$ (see Table 1).

It has been shown that once the CNTs are appropriately functionalized and intravenously injected into mice, they are excreted via the biliary pathway without causing any significant side effects. ${ }^{31}$ Generally CNTs can be either covalently or noncovalently functionalized with different chemical groups ${ }^{32}$ In terms of CNT reactivity with functional groups, researchers have divided CNTs into two zones, ie, the tips and the side walls. It has been shown that CNT tips have a higher affinity for binding functional groups than do the side walls. ${ }^{30}$

\section{Noncovalent functionalization}

Noncovalent functionalization involves Van der Waals interactions, $\pi-\pi$ interactions, and hydrophobic interactions of biocompatible functional groups with the surface of the CNT. One of the main advantages of this type of bonding is the minimal damage caused to the CNT surface. It has been suggested that noncovalent attachment preserves the aromatic structure and thus the electronic characteristics of CNTs. On the other hand, because noncovalent bonding provides a 
Table I Summary of most common techniques used for functionalization of carbon nanotubes

\begin{tabular}{|c|c|c|c|c|c|}
\hline CNT & CNT amount & Functionalization & Summary of techniques & Duration & Outcome \\
\hline MWCNT $^{84}$ & NA & $2.8 \mathrm{M} \mathrm{HNO}_{3}$ & Refluxing of MWCNT with $2.8 \mathrm{M}$ nitric acid & 72 hours & MWCNT-COOH \\
\hline MWCNT $^{84}$ & $100 \mathrm{mg}$ & $20 \mathrm{~mL} \mathrm{HNO}$ & $\begin{array}{l}\text { Sonicated, diluted, centrifuged }(50,000 \mathrm{~g} \text {, } \\
10 \text { minutes }) \text { and washed }\end{array}$ & $\begin{array}{l}\text { Sonicated } \\
60 \text { seconds }\end{array}$ & MWCNT-COOH \\
\hline MWCNT $^{85}$ & NA & $14 \mathrm{MHNO}_{3}$ & $\begin{array}{l}\text { Refluxed in } 14 \mathrm{M} \mathrm{HNO}_{3} \text { at } 80^{\circ} \mathrm{C} \text { for } \\
18 \text { hours, filtered with } 0.1 \mathrm{~mm} \text { PTFE } \\
\text { membrane in deionized water }\end{array}$ & 18 hours & MWCNT-COOH \\
\hline $\mathrm{MWCNT}^{73}$ & $500 \mathrm{mg}$ & $\begin{array}{l}25 \mathrm{~mL} \mathrm{H} \mathrm{SO}_{4} / \mathrm{HNO}_{3} \\
(3: 1, \mathrm{v} / \mathrm{v})\end{array}$ & $\begin{array}{l}\text { Refluxed and diluted with icy water. Excess } \\
\text { acid and water filtered. Solid washed with } \\
\mathrm{NaOH} \text { and } \mathrm{HCl} \text { to remove oxidation debris } \\
\text { and washed with distilled water. Dried } \\
\text { under vacuum }\end{array}$ & NA & MWCNT-COOH \\
\hline MWCNT $^{85}$ & NA & $5 \mathrm{MHNO}_{3}$ & $\begin{array}{l}\mathrm{I} \mathrm{cm}^{2} \text { of } \mathrm{MWCNT} / \mathrm{CC} \text { was placed in } \\
\text { a } 100 \mathrm{~mL} \text { Pyrex digestion tube } \\
\text { - Heated to } 210^{\circ} \mathrm{C} \text { in } 20 \text { minutes } \\
\text { with } 5 \mathrm{M} \mathrm{HNO}_{3} \\
\text { - The temperature was kept at } 210^{\circ} \mathrm{C} \\
\text { for } 30 \text { minutes (microwave power } 100 \mathrm{~W} \text { ) } \\
\text { - Filtered with } 0.1 \mathrm{~mm} \text { PTFE membrane in } \\
\text { distilled water }\end{array}$ & $\begin{array}{l}\text { Total modification } \\
\text { time }<\text { I hour }\end{array}$ & MWCNT-COOH \\
\hline MWCNT $^{86}$ & $\mathrm{I} \mathrm{mg}$ & G2-PAMAM & $\begin{array}{l}\text { MWCNT dispersed into N, N- } \\
\text { dimethylformamide (with the aid of } \\
\text { ultrasonication). Dried under an infrared } \\
\text { lamp. MWCNT-modified electrodes } \\
\text { immersed into } 10 \mathrm{mM} \text { EDC and } 2 \mathrm{mg} / \mathrm{mL} \\
\text { G2-PAMAM aqueous solution. Rinsed with } \\
\text { PBS and distilled water }\end{array}$ & $\begin{array}{l}\text { MWCNT in EDC: } \\
\text { I hour } \\
\text { MWCNT-EDC } \\
\text { in G2-PAMAM } \\
8 \text { hours }\end{array}$ & $\begin{array}{l}\text { G2 PAMAM/ } \\
\text { MWCNT }\end{array}$ \\
\hline SWCNT $^{89}$ & NA & $\begin{array}{l}\mathrm{HNO}_{3} / \mathrm{H}_{2} \mathrm{SO}_{4} \\
(\mathrm{I}: 3, \mathrm{v} / \mathrm{v})\end{array}$ & $\begin{array}{l}\text { Sonication in concentrated } \mathrm{HNO}_{3} / \mathrm{H}_{2} \mathrm{SO}_{4} \\
(\mathrm{I}: 3 \mathrm{v} / \mathrm{v}) \text { at } 70^{\circ} \mathrm{C} \text { then filtered, washed } \\
\text { with water, and dried }\end{array}$ & $\begin{array}{l}\text { Sonication } \\
4 \text { hours }\end{array}$ & SWCNT-COOH \\
\hline $\mathrm{SWCNT}^{20}$ & NA & 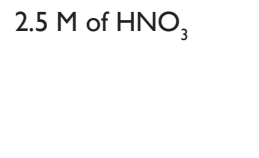 & $\begin{array}{l}\text { Refluxed, filtered, rinsed, and resuspended } \\
\text { in pure water with sonication. Centrifuged } \\
\text { (at } 7000 \mathrm{rpm} \text { for } 5 \text { minutes), larger } \\
\text { unreacted impurities removed }\end{array}$ & $2-36$ hours & SWCNT-COOH \\
\hline $\mathrm{SWCNT}^{61}$ & NA & $2 \mathrm{mg} / \mathrm{L}$ PL-PEG-NH${ }_{2}$ & $\begin{array}{l}\text { Mixed, sonicated, centrifuged ( } 13,000 \mathrm{rpm} \text {, } \\
3-4 \text { hours }) \text { and filtered }\end{array}$ & Sonication: I hour & PEG-SWCNT \\
\hline $\mathrm{SWCNT}^{88}$ & $6-10 \mathrm{mg}$ & $20 \mathrm{~mL} \mathrm{70 \%} \mathrm{HNO}_{3}$ & $\begin{array}{l}\text { Mixing performed in a microwave at } 900 \mathrm{~W} \text {, } \\
\text { then filtered, washed, and dried }\end{array}$ & $\begin{array}{l}\text { Microwave } \\
10-15 \text { minutes }\end{array}$ & SWCNT-COOH \\
\hline SWCNT $^{89}$ & $95 \mathrm{mg}$ & Piranha solution* & $\begin{array}{l}\text { SWCNT in Piranha solution heated at } \\
45^{\circ} \mathrm{C} \text { and stirred, cooled, filtered, } \\
\text { washed, and dried }\end{array}$ & $\begin{array}{l}\text { Stirring for } \\
90 \text { minutes }\end{array}$ & SWCNT-COOH \\
\hline $\begin{array}{l}\text { MWCNT- } \\
\mathrm{COOH}\end{array}$ & $0.30 \mathrm{~g}$ & $\begin{array}{l}3 \text { g amino } \\
\text { monomethyl } \\
\text { PEG-NH}\end{array}$ & $\begin{array}{l}\text { Mixing performed at } 130^{\circ} \mathrm{C} \text { under argon, } \\
\text { dispersed in distilled water, centrifuged } \\
\text { (at } 6000 \mathrm{rpm}, 30 \text { minutes) }\end{array}$ & $\begin{array}{l}\text { Mixing for } \\
\text { one week }\end{array}$ & PEG-g-MWCNT \\
\hline $\begin{array}{l}\text { SWCNT- } \\
\text { PL-PEG-NH2 } 2^{21}\end{array}$ & NA & $\begin{array}{l}\text { FITC I } 3 \mathrm{mM} \text {, } \\
50 \mu \mathrm{L}\end{array}$ & $\begin{array}{l}\text { FITC was dissolved in DMSO, and mixed } \\
\text { with I mL SWNT-PL-PEG-NH } \\
\text { solution. Incubated, filtered through } \\
100 \mathrm{kDa} \text { filters }\end{array}$ & $\begin{array}{l}\text { Mixture incubated } \\
\text { overnight }\end{array}$ & $\begin{array}{l}\text { SWCNT- } \\
\text { PL-PEG-FITC }\end{array}$ \\
\hline $\begin{array}{l}\text { SWCNT- } \\
\mathrm{COOH}^{90}\end{array}$ & $5 \mathrm{mg}$ & $\begin{array}{l}30 \mathrm{mg} \text { EDC } \\
\text { and } 300 \mathrm{mg} \mathrm{NHS}\end{array}$ & $\begin{array}{l}\text { EDC and NHS mixed in } 10 \mathrm{~mL} \text { buffer } \\
\text { solution of MES, shaken in a reciprocating } \\
\text { shaker. Filtered, rinsed, and redissolved } \\
\text { in } 10 \mathrm{~mL} \mathrm{MES.} \mathrm{I} \mathrm{mL} \mathrm{of} \mathrm{anti-Pgp} \mathrm{solution} \\
(0.025 \mathrm{mg} / \mathrm{mL}) \text { was added, and the mixture } \\
\text { shaken for } 2 \text { hours, filtered, and rinsed } \\
\text { with } 2 \mathrm{~mL} \text { of } \mathrm{NaCl} \text { solution }(0.1 \mathrm{M}) \text { until } \\
\text { no antibody detected }\end{array}$ & Mixing for 2 hours & Ap-SWCNT \\
\hline
\end{tabular}


Table I (Continued)

\begin{tabular}{|c|c|c|c|c|c|}
\hline CNT & CNT amount & Functionalization & Summary of techniques & Duration & Outcome \\
\hline $\begin{array}{l}\text { MWCNT- } \\
\mathrm{COOH}^{73}\end{array}$ & $\begin{array}{l}400 \mathrm{mg} \\
\text { MWCNT- } \\
\mathrm{COOH}\end{array}$ & $\begin{array}{l}20 \mathrm{~mL} \text { oxalyl } \\
\text { chloride }\end{array}$ & $\begin{array}{l}400 \mathrm{mg} \text { of } \mathrm{MW}-\mathrm{COOH} \text { in } 20 \mathrm{~mL} \text { of oxalyl } \\
\text { chloride was stirred at } 62^{\circ} \mathrm{C} \text {. Excess oxalyl } \\
\text { chloride was then eliminated in vacuo at } \\
60^{\circ} \mathrm{C} \text {. The resulting solution of MWCNT- } \\
\mathrm{COCl} \text { and } 20 \mathrm{~mL} \text { of } \mathrm{NH}_{2}\left(\mathrm{CH}_{2} \mathrm{CH}_{2} \mathrm{O}\right) \text { - } \\
2-\mathrm{CH}_{2} \mathrm{CH}_{2} \mathrm{NH}_{2} \text { in tetrahydrofuran refluxed, } \\
\text { cooled, filtered, and washed with methanol. } \\
\text { Air-dried at room temperature }\end{array}$ & $\begin{array}{l}\text { Stirring for } \\
24 \text { hours } \\
\text { Reflux for } \\
48 \text { hours }\end{array}$ & MWCNT-NH \\
\hline $\begin{array}{l}\text { SWCNT- } \\
\mathrm{COOH}^{88}\end{array}$ & $5 \mathrm{mg}$ & $\begin{array}{l}15-20 \mathrm{mg} \text { of } \\
\text { 2,6-dinitroaniline }\end{array}$ & $\begin{array}{l}\text { Mixing performed in a microwave at } 675 \mathrm{~W} \text {. } \\
\text { Then cooled, filtered, and washed } \\
\text { with DMF and THF }\end{array}$ & $\begin{array}{l}\text { Microwaved for } \\
\text { 15-20 minutes }\end{array}$ & $\begin{array}{l}\text { Amidated } \\
\text { SWCNT }\end{array}$ \\
\hline
\end{tabular}

Note: $* \mathrm{H}_{2} \mathrm{SO}_{4} 96 \%, \mathrm{H}_{2} \mathrm{O}_{2} 30 \%, 4: \mathrm{I} \mathrm{v/v.}$

Abbreviations: SWCNT, single-walled carbon nanotubes; MWCNT, multiwalled carbon nanotubes; NA, not applicable; PAMAM, polyamidoamine; PTFE, polytetrafluoroethylene; EDC, I-ethyl-3-(3-dimethylaminopropyl) carbodiimide hydrochloride; PBS, phosphate-buffered saline; PEG, polyethylene glycol; NHS, N-hydroxysulfosuccinimide; DMSO, dimethyl sulfoxide; MES, 2-(N-morpholino)ethanesulfonic acid; FITC, fluorescein isothiocyanate; DMF, dimethylformamide; THF, tetrahydrofuran; Pgp, permeability glycoprotein.

weak force between the functional group and the CNT, it is not suitable for targeted drug delivery applications. ${ }^{33}$

\section{Covalent functionalization}

Covalent binding of biocompatible groups to the surface of the CNT is another method of functionalization. Using this method, the surface of the CNT can be modified by different techniques, creating a suitable platform on the surface of these materials, enabling covalent attachment of biocompatible groups to the surface of CNTs. Oxidation of CNTs using strong acids is a method commonly used for generating covalent functionalization. ${ }^{22}$ Briefly, concentrated nitric acid, concentrated sulphuric acid, and CNTs are sonicated and heated. This process allows for side-wall covalent functionalization, and carboxylic acid groups would be attached, rendering CNTs water-soluble. Figure 2 shows a transmission electron microscopic CNT image before and after oxidization using a combination of nitric and sulfuric acid. These modifications would provide a suitable platform for the covalent attachment of biocompatible functional groups to the surface of the CNT, and the presence of a carboxylic group can improve CNT biocompatibility. It has
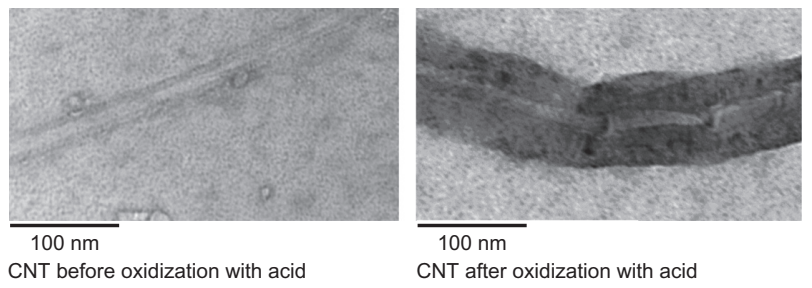

Figure 2 Carbon nanotubes (CNT) before and after oxidization using a combination of nitric and sulfuric acid. This method resulted in chemical modifications of carbon nanotubes and formation of carboxylate groups on the surface. been shown that a highly negative charge, developed as a result of the carboxylic group on the surface of the CNT, increases the hydrophilicity of these materials. ${ }^{22,23}$ Oxidized CNTs can then be further coated with PEG, a hydrophilic substance with the ability to make CNTs more biostable. ${ }^{21}$ Covalent binding of a functional group to the CNT can produce a stable functionalized CNT, making it more suitable for use as a vehicle for drug delivery. However, the side wall of the CNT is damaged during this process, resulting in alteration of other properties of the CNT. ${ }^{33,34}$ Hence, CNTs functionalized by covalent bonding should not be used in some applications, including imaging. ${ }^{31}$

\section{CNTs in drug delivery}

Chemotherapeutic agents have some limitations due to their toxic side effects. There is a niche in the pharmaceutical market for drug delivery that does not elicit such toxicity, whilst still having high therapeutic efficacy. Thus, there is an unmet need to develop cell-targeting drug formulations with a wide therapeutic index. CNTs have shown great promise as nanoscaled vehicles for targeted drug delivery. ${ }^{15,35}$ One of the main advantages of the CNT is its ability to deliver drugs directly to cancer cells. ${ }^{12,36}$ In the past, there have been numerous experimental studies performed in vitro and in vivo using antibody-functionalized CNTs loaded with chemotherapeutic agents. Another application of CNTs for drug delivery is intravenous injection. One of the issues with injecting drugs into the body is the risk of blood vessels becoming blocked because of the large size of the drugs, which would lead to tissue toxicity. It has been suggested that CNTs could be used as nanocarriers for delivering drugs into the body via injectable routes. ${ }^{12}$ It is beyond the scope 
of this article to describe all of them in detail, but they have been succinctly summarized in a series of recent reports (see Table 2). Drugs can either attach to the outer surface of the CNT via functional groups or be loaded inside the CNT. Attachment of the anticancer drug to the outer surface of the
CNT can be through either covalent or noncovalent bonding, including hydrophobic, $\pi-\pi$ stacking, and electrostatic interactions. ${ }^{5,37,38}$ Filling of the CNT with the anticancer drug is another method of incorporating drugs to CNTs, which will also be discussed in this review.

Table 2 Summary of drug delivery via carbon nanotubes

\begin{tabular}{|c|c|c|c|c|}
\hline CNT & Type of cancer/disease & In vivo/in vitro & Drug & Method of loading \\
\hline SWCNTs ${ }^{18}$ & Ovarian cancer & NA & Gemcitabine & Use of external forces to particles in a selected direction \\
\hline SWCNTs $^{91}$ & Leukemia & In vitro & Daunorubicin & $\begin{array}{l}\text { Daunorubicin incubated in phosphate-buffered saline } \\
\text { at } 37^{\circ} \mathrm{C} \text { for } 16 \text { hours with SWCNTs }\end{array}$ \\
\hline Not specified ${ }^{46}$ & $\begin{array}{l}\text { Leishmania donovani } \\
\text { (parasite) }\end{array}$ & $\begin{array}{l}\text { In vitro and } \\
\text { in mice }\end{array}$ & Amphotericin B & $\begin{array}{l}\text { Carboxylated CNTs were treated with }\left[\mathrm{NH}_{2}\left(\mathrm{CH}_{2}\right)_{2} \mathrm{NH}_{2}\right] \text {, } \\
\text { forming amine groups on the CNT surface. Amino CNTs } \\
\text { were dispersed in distilled water. This solution was mixed } \\
\text { with f-CNT solution and sonicated in an ultrasonication } \\
\text { bath for } 24 \text { hours }\end{array}$ \\
\hline SWCNTs $^{5}$ & Breast cancer & $\begin{array}{l}\text { In vitro and } \\
\text { in mice }\end{array}$ & Paclitaxel & $\begin{array}{l}\text { Paclitaxel was modified by succinic anhydride, adding } \\
\text { a carboxyl group at the C-2-OH position } \\
\text { SWCNTs with branched PEG-NH } \text { functionalization were }_{2} \\
\text { reacted with modified paclitaxel in the presence of EDC } \\
\text { and NHS }\end{array}$ \\
\hline $\mathrm{MWCNTs}^{37}$ & $\begin{array}{l}\text { Human } \\
\text { gastric carcinoma }\end{array}$ & $\begin{array}{l}\text { In vitro and } \\
\text { in mice }\end{array}$ & HCPT & $\begin{array}{l}\text { HCPT is linked to MWCNTs using diaminotriethylene } \\
\text { glycol (hydrophilic spacer) biocleavable ester linkage }\end{array}$ \\
\hline $\mathrm{SWCNTs}^{4}$ & $\begin{array}{l}\text { Chorio- (JAR), } \\
\text { nasopharyngeal } \\
\text { epidermoid (KB), } \\
\text { testicular carcinoma }\end{array}$ & In vitro & Platinum (IV) & $\begin{array}{l}\text { The SWCNT-PL-PEG-NH }{ }_{2} \text { was initially formed. } \\
\text { The SWCNT coated with PEG was then reacted with } \\
\text { the platinum in the presence of coupling agents including } \\
\text { EDC and NHS }\end{array}$ \\
\hline Not specified ${ }^{35}$ & Bladder cancer & In vitro & Carboplatin & $\begin{array}{l}\text { CNT suspension in carboplatin solution }(10 \mathrm{mg} / \mathrm{mL}) \\
\text { Sonication for } 10 \text { minutes and stirring for } 24 \text { hours } \\
\text { at various temperatures }\end{array}$ \\
\hline $\mathrm{MWCNTs}^{42}$ & Breast cancer & In vitro & Doxorubicin & $\begin{array}{l}\text { MWCNT dispersion using I\% Pluronic }{ }^{\circledR} \text { FI } 27 \text { solution } \\
\text { ([MWCNT] I mg/mL) by bath sonications for } 30 \text { minutes. } \\
\text { Doxorubicin and Pluronic-MWCNT were mixed in equal } \\
\text { volumes of doxorubicin hydrochloride with increasing } \\
\text { MWCNT aqueous dispersion concentrations }\end{array}$ \\
\hline SWCNTs $s^{52}$ & Cervical cancer & In vitro & siRNA & $\begin{array}{l}\text { SWCNTs reacted with PL-PEG. For the incorporation } \\
\text { of disulfide bond, the amide group of PEG was attached } \\
\text { to a heterobifunctional crosslinker (sulfo-LC-SPDP). The } \\
\text { siRNA was then attached to SWCNTs via a disulfide bond }\end{array}$ \\
\hline $\mathrm{SWCNTs}^{43}$ & Lymphoma & In SCID mice & Doxorubicin & $\begin{array}{l}\text { SWCNTs were sonicated in a solution of PL-PEG followed } \\
\text { by centrifugation. Excess surfactant was removed by } \\
\text { filtration and washing. Doxorubicin loading onto } \\
\text { pegylated SWCNTs was carried out by mixing }\end{array}$ \\
\hline$M W C N s^{51}$ & Breast cancer & In vitro & Methotrexate & $\begin{array}{l}\text { Amine-MWCNTs was generated through I,3-dipolar } \\
\text { cycloaddition reaction of azomethineylides. Methotrexate } \\
\text { was reacted with f-MWCNTs through coupling agents, ie, } \\
\text { HATU and DIEA }\end{array}$ \\
\hline $\mathrm{SWCNTs}^{5}$ & $\begin{array}{l}\text { Breast cancer } \\
\text { (4TI murine cell line) }\end{array}$ & In vitro & Paclitaxel & $\begin{array}{l}\text { Paclitaxel conjugated to branched PEG chains on SWCNTs } \\
\text { via a cleavable ester bond to obtain a water soluble } \\
\text { SWCNT-paclitaxel }\end{array}$ \\
\hline $\mathrm{SWCNTs}^{33}$ & Lymphoma & In vivo & Doxorubicin & $\begin{array}{l}\text { Supramolecular } \pi-\pi \text { stacking to load a cancer } \\
\text { chemotherapy agent doxorubicin onto branched } \\
\text { polyethylene glycol functionalized SWCNTs for } \\
\text { in vivo drug delivery applications }\end{array}$ \\
\hline $\mathrm{SWCNTs}^{92}$ & NA & In mice & $\begin{array}{l}\text { Metal halides } \\
\left(\mathrm{Na}{ }^{125}\right.\end{array}$ & $\begin{array}{l}\text { Metal halides were sealed inside SWCNTs to create } \\
\text { high-density radioemitting crystals }\end{array}$ \\
\hline
\end{tabular}

Abbreviations: CNTs, carbon nanotubes; SWCNTs, single-walled carbon nanotubes; MWCNTs, multiwalled carbon nanotubes; NA, not applicable; EDC, I-ethyl3-(3-dimethylaminopropyl) carbodiimide hydrochloride; PEG, polyethylene glycol; NHS, N-hydroxysulfosuccinimide; HCPT, I0-hydroxycamptothecin; siRNA, small interfering RNA; PL, platinum; f-CNT, functionalized CNT; HATU, O-(7-azabenzotriazol-I-yl)-N,N,N',N'-tetramethyluronium hexafluorophosphate; DIEA, diisopropylethylamine. 


\section{Covalent drug attachment to CNTs}

Different methods of drug loading and attachment to the CNT suggest the need for use of a linker, with which both the drug and CNT react to form covalent bonds..$^{39,40}$ Researchers at Stanford University have delivered paclitaxel to cancer cells by covalent attachment of paclitaxel to the outer surface of the SWCNT. In this experiment, paclitaxel was initially reacted with succinic anhydride, which resulted in addition of carboxylic acid groups on the surface of paclitaxel. Subsequently, SWCNTs were sonicated in a $0.2 \mathrm{mmol} / \mathrm{L}$ solution of DSPE-PEG 5000-4-arm-(PEG-amine) for 30 minutes using a cuphorn sonicator followed by centrifugation at $24,000 \mathrm{~g}$ for 6 hours. This resulted in formation of SWCNTs noncovalently attached to $\mathrm{PEG}-\mathrm{NH}_{2}$. The product was then reacted with the carboxylic acid-coated paclitaxel, in the presence of coupling agents, ie, 1-ethyl-3-(3-dimethylaminopropyl) carbodiimide hydrochloride (EDC) $5 \mathrm{mmol} / \mathrm{L}$ and N-hydroxysulfosuccinimide (NHS) $5 \mathrm{mmol} / \mathrm{L}$. Unconjugated paclitaxel was subsequently removed by filtration. Ultraviolet-visible near infrared spectra of SWCNTs before and after conjugation with paclitaxel were then obtained. The absorbance peak of paclitaxel was used to demonstrate the loading of paclitaxel onto the SWCNTs, and the result was confirmed by radiolabel-based assay. In vitro delivery of paclitaxel attached to SWCNTs showed higher efficacy in suppressing tumor growth than delivery of paclitaxel alone. This suggests that higher concentrations of paclitaxel were delivered to breast cancer cells using SWCNT-paclitaxel conjugates in comparison with delivery of paclitaxel alone. ${ }^{5}$

Another group of researcher have attempted to deliver an antitumor agent, 10-hydroxy camptothecin (HCPT), by covalent attachment to the outer surface of the MWCNT. In the same way as above, the HCPT was reacted with succinic anhydride in order to obtain carboxylic groups on its surface. Amino groups were then introduced to the MWCNTs. CNTs coated with amino groups and HCPT functionalized by carboxylic groups were then reacted together in the presence of NHS and EDC as coupling agents. The excess HCPT was then removed using a filtration technique. Ultraviolet-visible near infrared spectrometry was then used to confirm linkage of the MWCNTs to HCPT. ${ }^{37}$

Platinum (IV) has also been delivered to cancer cells by conjugation to SWCNTs. As in the aforementioned studies, SWCNTs were initially sonicated with platinum (IV)-PEG-NH $\mathrm{N}_{2}$ for 1 hour. This was followed by centrifugation at $2.4 \times 10^{4} \mathrm{~g}$ for 6 hours to remove catalysts and large aggregates, and ultrafiltration to remove excess free platinum (IV)-PEG-NH $\mathrm{N}_{2}$. The treated SWCNTs and the functionalized platinum (IV) were then reacted together. Platinum (IV) attached to SWCNTs, achieved higher rates of cell death than when platinum alone was injected into the cancer cells. The enhanced cytotoxicity obtained using the platinum (IV)SWCNT complex suggests that SWCNTs can mediate the delivery of platinum (IV) and hence improve cellular uptake of the drug. ${ }^{4}$

\section{Noncovalent drug attachment to CNTs}

In addition to covalent attachment, anticancer drugs can also attach to the surface of the CNT by noncovalent bonding. This involves physical conjugation of the drug to CNT via $\pi-\pi$ stacking, hydrophobic interaction, or electrostatic adsorption. Although covalent attachment is a very feasible procedure, it has been suggested that this may cause chemical changes in anticancer drugs, implying that their efficacy can potentially be altered. ${ }^{33}$ However, one of the disadvantages of noncovalent bonding is the lack of efficient attachment, potentially resulting in release of the drug before it reaches its site of action. ${ }^{20,41}$ An example of noncovalent attachment of an anticancer drug in this context is the attachment of doxorubicin to MWCNTs. In one experiment, MWCNTs were dispersed in $1 \%$ Pluronic ${ }^{\circledR}$ F127 solution until a final MWCNT concentration of $1 \mathrm{mg} / \mathrm{mL}$ was formed. The solution was then bath-sonicated for 30 minutes. Increasing concentrations of Pluronic-MWCNT $(10,20$, and $40 \mu \mathrm{g} / \mathrm{mL})$ were then reacted with doxorubicin $20 \mu \mathrm{g} / \mathrm{mL}$. The interaction between the MWCNTs and doxorubicin was studied using luminescence spectrometry. The results showed that the fluorescence intensity of doxorubicin decreased with increasing concentrations of MWCNT. This suggests that as the concentration of the MWCNT increases, more platforms become available for noncovalent $\pi-\pi$ interaction of doxorubicin with the surface of the MWCNT. ${ }^{42}$ In another experiment, pegylated CNTs were reacted with doxorubicin, resulting in doxorubicin becoming loaded onto the PEG that was covering the surfaces of the CNTs. It was suggested that, due to the aromatic nature of doxorubicin, noncovalent binding of this molecule onto the surface of the CNT was most likely because of $\pi-\pi$ stacking and hydrophobic interactions.

SWCNTs attached noncovalently to doxorubicin were then used for in vitro and in vivo experiments. The SWCNT-doxorubicin complex showed greater toxicity than doxorubicin alone to cancer cells in vitro, suggesting doxorubicin release from the SWCNTs inside cell endosomes and lysosomes. In one in vivo study, doxorubicin alone and SWCNT-doxorubicin were injected into SCID mice bearing 
Raji lymphoma xenografts. The mice were sacrificed 6 hours after injection, and the major organs were investigated for doxorubicin content. A larger amount of doxorubicin was found in the organs when the drug was conjugated to CNTs. This study also showed that doxorubicin was successfully delivered by SWCNTs to target organs in mice. ${ }^{43}$

\section{Loading CNTs with anticancer drugs}

Filling CNTs with an appropriate anticancer drug is another method of delivering anticancer therapy. According to Arsawang et al, a CNT with a diameter of $80 \mathrm{~nm}$ can hold up to 5 million drug molecules. ${ }^{18}$ Several strategies have been used to incorporate drugs into CNTs. One of these methods is steered molecular dynamic simulation. The general principle of steered molecular dynamics involves applying an external force to particles in a specific direction by use of harmonic (spring-like) restraint in order to create greater change of the particle coordinates. In an experiment carried out by researchers in Thailand, gemcitabine, an anticancer drug, was loaded onto SWCNTs using a steered molecular dynamic technique. Following application of force to the gemcitabine, it was shown that the cytosine ring of gemcitabine formed $\pi-\pi$ stacking on the internal surface of the CNT with 25 Angstrom far from one end of the SWCNT. ${ }^{18}$

The wet chemical technique is also commonly used. An example of this method comes from a study in which a $1 \mathrm{mg} / 1 \mathrm{~mL}$ suspension of open-ended CNTs was placed in a $10 \mathrm{mg} / 1 \mathrm{~mL}$ carboplatin solution, with sonication of the mixture for 10 minutes, followed by stirring for 24 hours. Optical investigations of the sample obtained was performed using transmission electron microscopy (Figure 3), energy dispersive X-ray analysis, electron energy loss spectroscopy, and X-ray photoelectron spectroscopy, all of which established the presence of carboplatin inside the CNTs. The quantity of carboplatin was also determined by inductively coupled plasma optical emission spectrometry. After a considerable number of investigations at temperatures of $30^{\circ} \mathrm{C}-90^{\circ} \mathrm{C}$, researchers in Germany found that the amount of drug loaded onto CNTs increases at higher temperatures, and that when the temperature exceeded $70^{\circ} \mathrm{C}$, the concentration of anticancer drug inside the CNT increased dramatically (Figure 4). A disadvantage of loading CNTs using the wet chemical technique is that some of the drug binds to the exterior of the CNT. To avoid this, it has been suggested to coat the CNTs prior to loading and subsequently wash them with water and ethanol. ${ }^{35}$

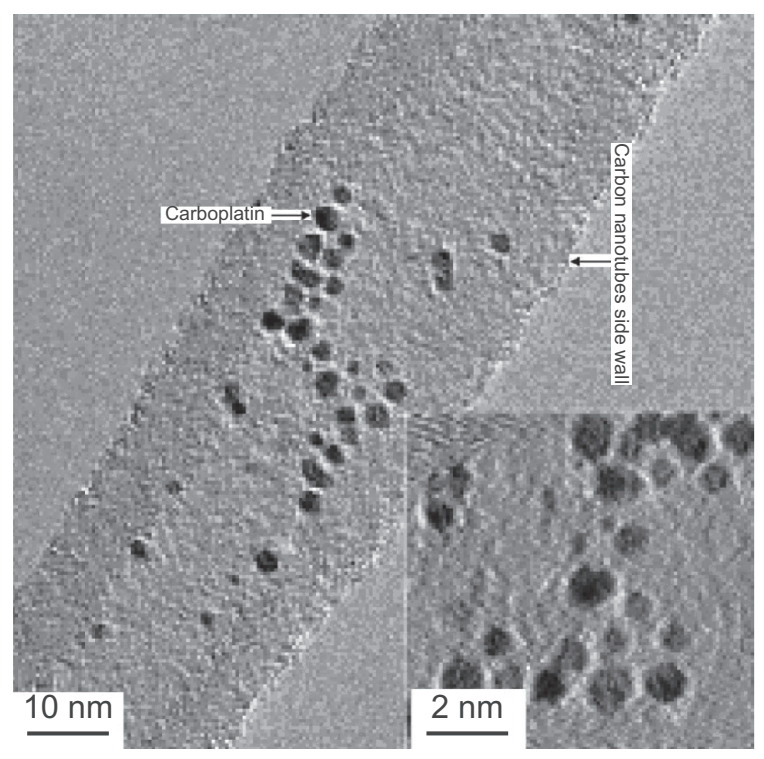

Figure 3 Loading anticancer drugs onto carbon nanotubes. A wet chemical approach is applied in which the capillary is the driving force for incorporating the anticancer drugs into the open-ended carbon nanotubes. ${ }^{35}$

Adapted from Nanomedicine (Lond), Hampel et al, Vol 3, Issue 2, Pp. I75-182. Copyright (2008) Future Medicine Ltd. Reproduced with permission.

To determine the release profile of carboplatin-loaded CNTs, the conjugates were added to Dulbecco's modified Eagle's medium at varying $\mathrm{pH}$ for 14 days. Atomic absorption spectrometry was then used to measure carboplatin release into the culture medium. At day 0 , only 3\%-5\% of the carboplatin was released, whilst approximately $55 \%$ and $68 \%$ (at $\mathrm{pH} 5$ and $\mathrm{pH} 8$, respectively) of the carboplatin was released from the CNTs after 14 days. This indicates a gradual and sustained release of carboplatin after loading into CNTs and possibly enhanced carboplatin release from carboplatin-loaded CNTs at higher $\mathrm{pH}$ values. ${ }^{44}$

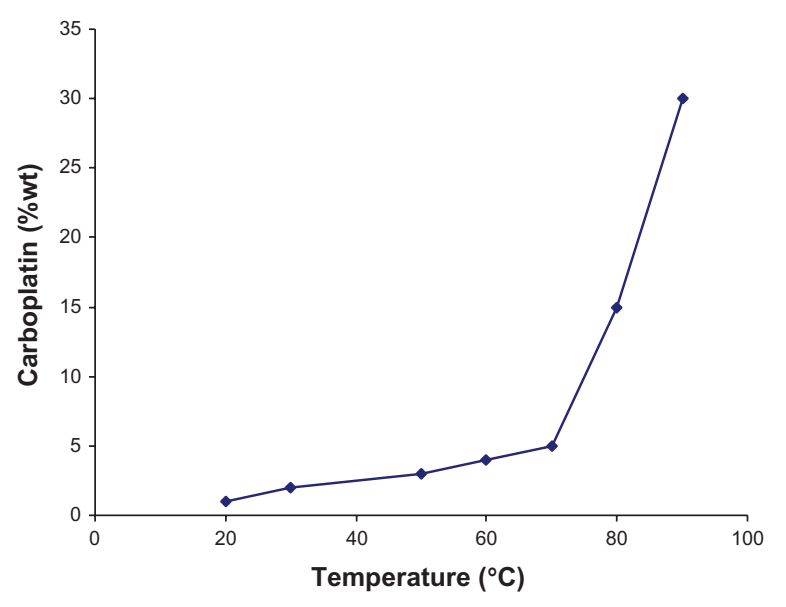

Figure 4 Relationship between temperature and anticancer drug loading. A larger amount of drug can be loaded onto carbon nanotubes as temperature increases, especially in the temperature range of $70^{\circ} \mathrm{C}-90^{\circ} \mathrm{C} .^{35}$

Adapted from Nanomedicine (Lond), Hampel et al, Vol 3, Issue 2, pp. 175-182. Copyright (2008) Future Medicine Ltd. Reproduced with permission. 


\section{Cellular targeting and uptake of CNTs}

The question arises as to how anticancer drug-loaded CNTs can recognize their site of action and the routes by which CNTs can be delivered to target cells. A number of methods have been used by various research groups to investigate how the anticancer drug-loaded CNT might recognize the cancer cell. One of the major techniques used involves coating the surface of the CNT with a particular antibody having affinity for the target cancer cell.

According to the National Institute of Standards and Technology, all antibodies that have been used for cell targeting have been monoclonal IgG antibodies. However, experiments have recently been carried out using IgY as a substitute for IgG. IgY has shown some biochemical, immunological, and production-related advantages in comparison with $\operatorname{IgG} .^{45,46}$ Other observations show that the attachment of antibodies to the CNT surface does not lead to alteration of antibody specificity for the target cell. It has been shown that the antibody can successfully deliver anticancer drug-loaded CNTs to the site of action. For example, Ashcroft et al found that more than 40 CNT-anti cancer drug complexes could be targeted as a result of coating the CNT with ZME-108, a specific type of skin cancer antibody. ${ }^{47}$ In another experiment, a SWCNT functionalized by PEG and rituxan (the monoclonal antibody against CD20, found primarily on B cells), selectively targeted the CD20 cell surface receptor on B cells with little binding to T cells. ${ }^{12}$

In addition to coating CNT successfully with functional groups, such as antibodies, to achieve cell specificity, another important issue is being able to track the course of CNTs in the living organism. For this purpose, quantum dots, which have the ability to generate fluorescence when exposed to certain wavelengths of light, ${ }^{48}$ and have been functionalized to the walls of CNTs.

There is still debate about the exact mechanism by which CNTs enter cells. However, two main routes have been described in the literature. These are passive diffusion of CNTs through the lipid bilayers of the cell membrane and attachment of CNTs to the external cell membrane, resulting in its absorption by the cell using an energy-dependent process, such as endocytosis. The exact mechanism of CNT uptake is determined by various factors, such as size, shape, degree of dispersion, and the formation of supramolecular CNT complexes.

One group of researchers has reported that small CNTs with a length of up to $400 \mathrm{~nm}$ are internalized by a diffusion mechanism and that CNTs larger than $400 \mathrm{~nm}$ in length are internalized by endocytosis. ${ }^{49}$ It has also been suggested that CNTs attached to large proteins, such as streptavidin, staphylococcal protein A, or bovine serum albumin, are taken up via endocytosis, whereas CNTs attached to small molecules, such as ammonium, methotrexate, or amphotericin B, enter cells by a diffusion process. ${ }^{13}$

MWCNTs and SWCNTs differ in their mechanism of cell penetration. Confocal microscopy imaging has shown that SWCNTs have the ability to be internalized into cells, whereas MWCNTs are excluded from the interior of the cell. Size of the CNTs also influences their cellular uptake and fate, because long SWCNTs are shown to be localized in the cytoplasm, whilst short SWCNTs are transported into the nucleus (Figure 5). ${ }^{50}$
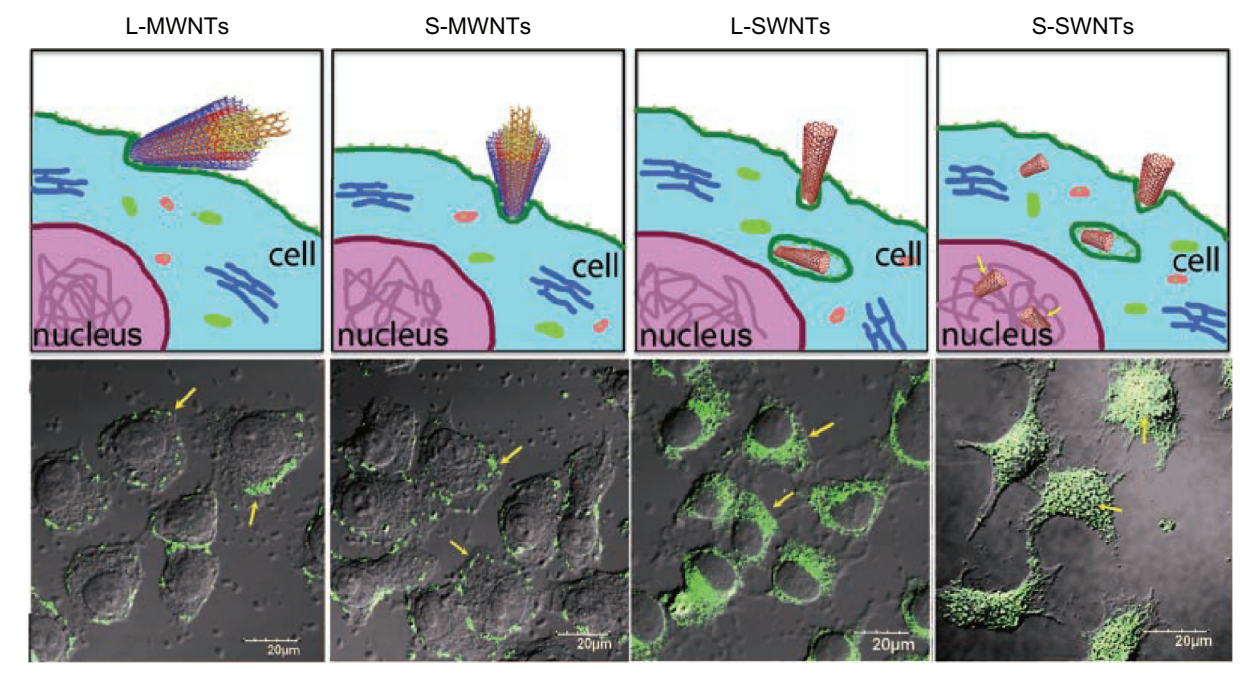

Figure 5 Confocal microscopy shows that the single-walled carbon nanotubes have the ability to be internalized into the cells whereas the multiwalled carbon nanotubes are excluded from the interior. Also in terms of the influence of the size it has been shown that the long single-walled carbon nanotubes are localized only in the cytoplasm but the short single-walled carbon nanotubes are transported into the nucleus. ${ }^{50}$

Adapted from Kang et al: Cell response to carbon nanotubes: Size-dependent intracellular uptake mechanism and subcellular fate. Small. 20I0. Vol. 6. Pp. 2362-2366. Copyright Wiley-VCH Verlag GmbH \& Co KGaA. Reproduced with permission. 


\section{Drug release from CNTs}

An important aspect of CNT drug delivery systems is the mechanism by which drug is released to target the cancer cell upon entry of the CNT-drug conjugate into the cell. Different modes of drug release from CNTs in the targeted cell have been described in the literature. Substantial data describing the rate and amount of drug release from CNTs are lacking. Different reports have shown that once the drug is loaded into the CNT, it will be excreted from the tube into the cellular environment, ${ }^{13}$ but there is no accurate quantification of the amount of drug released. ${ }^{21}$ One of the novel ideas is to load CNTs with drugs and seal the two ends of the CNT with molecules that can be cleaved off intracellularly. Alternatively, the drug can be attached to the CNT through a linker, such as disulfide, which is susceptible to cleavage under the influence of various factors, such as $\mathrm{pH}$ changes, heat, and reducing agents. ${ }^{51,52}$ It has been observed that, as the environmental $\mathrm{pH}$ becomes acidotic, more doxorubicin is released from the CNT-doxorubicin conjugate. At a $\mathrm{pH}$ of 5.5 , the approximate release of doxorubicin from the CNT is approximately $40 \%$ in 1 day. Because the microenvironment of the extracellular tumor tissue and intracellular lysosomes and endosomes is acidotic, release of doxorubicin in these environments occurs with a higher magnitude. ${ }^{43}$

In a similar experiment, small interfering RNA (siRNA) was attached to the CNT surface with the aid of disulfide bonding and delivered to the targeted cell. The results of this experiment showed that, on endocytotic entry of the CNT-siRNA, the disulfide bond was cleaved off by the thiolreducing enzyme and siRNA was released. This process was aided by the acidic $\mathrm{pH}$ in the lysosomes. ${ }^{52}$
Apart from an acidic environment, the element of heat can also be useful for the release of drugs. CNT was initially reacted with acid to form carboxyl groups at the open ends of the CNT tube, and (2-aminopethylthiol)-2-thiopyridine was then reacted with CNT-COOH to form thio-pyridine-functionalized CNT ends. Following filling of the tube with fluorescein, the tube was then sealed by the addition of silica nanospheres. The silica was conjugated to the ends of the CNT by means of thiol groups. CNTs were shown to reopen after exposure to heat as a result of cleavage of the disulfide bonds. Once opened, the contents were released. In other words, controlled cap ejection governs the release of contents within the CNTs (Figure 6). ${ }^{35,53}$

\section{CNTs in thermal ablation of cancer cells}

There is much interest into the use of CNTs in conjunction with radiofrequency and laser therapy in cancer treatment. Thermal ablation represents a potential form of cancer therapy that is noninvasive and harmless to normal cells, with high efficacy.

This section looks into the ways in which cancer cells can be ablated using high temperature. Generally, the thermal ablation method involves heating cells at temperatures above $55^{\circ} \mathrm{C}$, which results in coagulative necrosis and protein denaturation of the cell, thus disabling functioning of the targeted cells. ${ }^{21,54}$

Over the last 3 years, research has been conducted into the development of nanostructures that produce heat on activation by near infrared optical excitation. These particular nanostructures would be able to target the malignant tumor site specifically and selectively ablate tumor cells, leaving

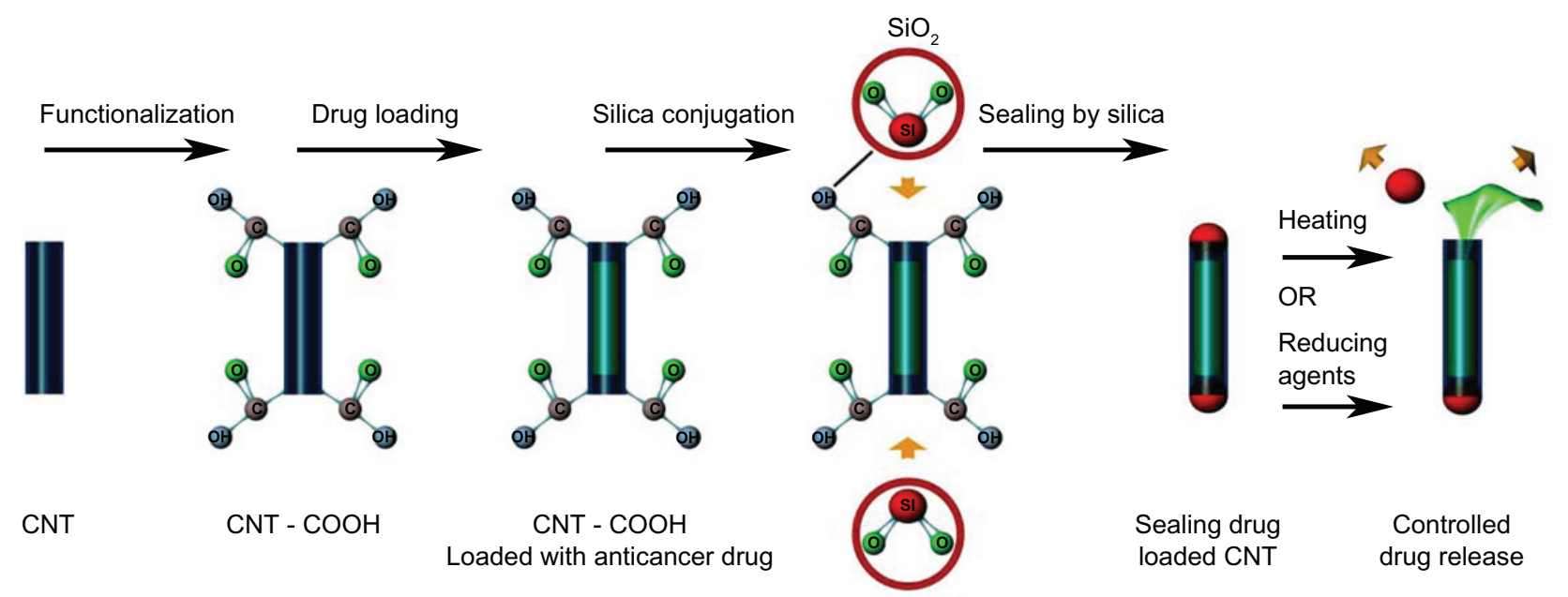

Figure 6 The picture illustrates that the silica can be used to seal the two ends of the drug-loaded carbon nanotubes (CNT). This is used to allow the drugs to be released in controlled manner. 
nearby healthy tissue relatively unharmed, providing a far less invasive alternative to surgery.

Exposure to modalities, such as near infrared, leads to cell death by irreversible protein denaturation or plasma membrane damage as a result of temperatures reaching over $40^{\circ} \mathrm{C}$. This form of therapy has been shown to be efficacious for the treatment of numerous malignancies, including those of the lung, liver, and prostate. Zavaleta et al observed that a modest temperature increase of $3^{\circ} \mathrm{C}-5^{\circ} \mathrm{C}$ was sufficient to cause protein denaturation in cells, leading to the death of malignant cells. ${ }^{55}$ The transmission of laser beams could be divided into two different types, ie, short laser nanosecond exposure and long laser exposure. Nanosecond exposure is usually used for the ablation of metastatic or individual tumor cells. Although temperatures using this method can reach a maximum of $300^{\circ} \mathrm{C}$, its nanosecond exposure ensures minimal damage to surrounding tissues. ${ }^{55,56}$ The second method requires a few minutes of laser exposure and is generally used for ablation of primary cancer cells that are relatively large in size. The latter usually disables cell function by thermal protein denaturation and, unlike short laser exposure, may affect healthy cells as well as cancer cells. The temperature range for this type of laser is typically $45^{\circ} \mathrm{C}-65^{\circ} \mathrm{C}$. To overcome the risk of death of healthy cells, researchers at Arkansas University produced a laser beam that generates a higher temperature in the range of $80^{\circ} \mathrm{C}-95^{\circ} \mathrm{C}$. This is high enough to kill cancer cells but has a minimal effect on surrounding healthy tissue due to the shorter exposure time required..$^{21,57}$ Targeted killing of cancer cells using heat-generating lasers is performed in clinical practice at present, but current techniques have problems, such as the laser being a single point source of thermal energy that results in uneven tumor heating, or production of tumor seeding along the needle track that can result in tumor recurrence. ${ }^{21,58}$ Various experiments have shown that CNT-mediated thermal ablation can overcome such limitations and generate effective heating and thermal ablation of tumor cells. Also, laser-stimulated CNT produces temperature gradients that extend more deeply into the tissue than laser treatment alone..$^{59}$ Exposing CNTs to radiofrequency can also increase the temperature of these materials. Gannon et al showed in both in vitro and in vivo experiments that once CNTs are exposed to radiofrequency they can thermally destroy cancer cells $^{60}$ (Table 3 ).

One way of finding out more about the effects of temperature changes in organs and of understanding whether the tissues are affected by heat production is to conduct a heat shock protein analysis. Heat shock protein works as an endogenous marker of thermal stress and is induced by elevated temperature (typically in excess of $43^{\circ} \mathrm{C}$ ). Researchers have shown that when cancer cells are exposed to laser alone, heat shock protein expression is induced proximal to the incident laser and gradually diminishes more distal to it. In contrast, when the laser is exposed to CNTs, the heat generated from these materials is high enough to increase the surface temperature of the cells and cause coagulative necrosis. As a result, heat shock protein induction is seen in deeper tissue, indicating that CNTs can be used to extend the depth of thermal therapy. ${ }^{59}$

The temperature of CNTs can increase to over $60^{\circ} \mathrm{C}$ within 2 minutes when they are exposed to near infrared wavelengths of 700-1100 nm. ${ }^{21}$ At the same time, it has been found that, because of the lack of specific chromophores, normal cells and biological systems are highly transparent to this range of wavelengths. This has led to recent interest in the effect of near infrared light on CNTs used for thermal treatment of cancer. Carrying out the experiments in vitro is crucial, but there are critical issues in conducting the same experiments in vivo. For example, it is imperative to delineate the difference between using CNTs for thermal ablation of cancer cells in vitro as opposed to in vivo.

In one experiment, a group of mice were injected with human epidermoid cancer cells. Once the size of the tumor reached $70 \mathrm{~mm}^{3}$, functionalized CNTs were injected into the tumors which were then exposed to near infrared. The results showed that the cancerous cells treated with CNTs and near infrared light disappeared within 20 days (Figure 7). ${ }^{61}$ It was also shown that a local rise in temperature increased the permeability of the tumor vasculature which may be advantageous for selective delivery of drugs to the tumor site from the systemic circulation..$^{59,62}$

In addition to CNT, magnetic nanoparticles can also be used for thermal treatment of cancer. Magnetic nanoparticles can be localized in deep tissue, an external magnetic field can then fix them at a specific position, and alteration of the AC field can be used to change the temperature of the magnetic nanoparticles. However, toxicity and oxidation of the magnetic nanoparticles in the biological setting must be avoided.

Insertion of magnetic nanoparticles inside the CNTs could be a way to overcome this issue. The CNT could act as a shell, protecting the biological environment against oxidation and toxicity of the magnetic nanoparticles. The other benefit of using CNTs is the fact that the magnetic properties of these materials are not altered by their insertion into CNTs, and so they can still be used for thermal ablation of cancer. ${ }^{63}$ 
Table 3 Thermal ablation using carbon nanotubes. Effect of various wavelengths and power of near infrared laser on temperature change of different types of carbon nanotubes in an in vivo experiment

\begin{tabular}{|c|c|c|c|c|c|c|}
\hline CNTs & Cell type & In vitro/in vivo & Cancer type & $\lambda$ NIR/Power & Antibody & Outcome/comments \\
\hline SWCNTs $^{45}$ & $\begin{array}{l}\text { HER2-expressing, } \\
\text { SK-BR-3 cells }\end{array}$ & In vitro & Breast cancer & $\begin{array}{l}820 \mathrm{~nm}, 0.8 \mathrm{~W} / \mathrm{m}^{2} \text {, } \\
7 \text { minutes }\end{array}$ & $\begin{array}{l}\text { Horseradish } \\
\text { peroxidase- } \\
\text { labeled lgG }\end{array}$ & $\begin{array}{l}\text { Increased cytotoxicity } \\
\text { with SWCNTs NIR radiation }\end{array}$ \\
\hline SWCNTs $^{93}$ & Daudi cells & In vitro & $\begin{array}{l}\text { Burkitt's } \\
\text { lymphoma }\end{array}$ & $\begin{array}{l}808 \mathrm{~nm}, 5 \mathrm{~W} / \mathrm{cm}^{2} \text {, } \\
7 \text { minutes }\end{array}$ & $\begin{array}{l}\text { anti-CD22 mAb; } \\
\text { CD22, CD25 }\end{array}$ & $\begin{array}{l}\text { Increased cytotoxicity } \\
P<0.05\end{array}$ \\
\hline MWCNTs $^{94}$ & - & In vitro & - & $\begin{array}{l}650 \mathrm{~nm} / 2.5 \mathrm{~mW} \\
1064 \mathrm{~nm} / 390 \mathrm{~mW}\end{array}$ & - & $\begin{array}{l}\text { Temperature increase } \\
7^{\circ} \mathrm{C} \text { above controls } \\
\text { Temperature increase } \\
\text { of }>100^{\circ} \mathrm{C} \text { above controls }\end{array}$ \\
\hline SWCNTs ${ }^{61}$ & $\mathrm{~KB}$ cells & In nude mice & $\begin{array}{l}\text { Human } \\
\text { epidermoid } \\
\text { mouth cancer }\end{array}$ & $808 \mathrm{~nm}, 3.8 \mathrm{~W} / \mathrm{cm}^{3}$ & - & $\begin{array}{l}\text { Intratumoral injection of PEG- } \\
\text { SWCNTs and NIR irradiation } \\
\text { resulted in tumor death after } \\
20 \text { days }\end{array}$ \\
\hline $\mathrm{SWCNTs}^{54}$ & CT26.WT cells & In mice & $\begin{array}{l}\text { Colon } \\
\text { carcinoma }\end{array}$ & $\begin{array}{l}808 \mathrm{~nm}, 4 \mathrm{~W} / \mathrm{cm}^{2}, \\
3 \text { minutes }\end{array}$ & - & $\begin{array}{l}\text { Complete regression } \\
\text { Mice remained healthy and } \\
\text { tumor-free }>90 \text { days } \\
\text { after treatment }\end{array}$ \\
\hline SWCNTs ${ }^{95}$ & Daudi cells & In SCID mice & $\begin{array}{l}\text { Burkitt's } \\
\text { lymphoma }\end{array}$ & $\begin{array}{l}805-811 \mathrm{~nm}, \\
9.5 \mathrm{~W} / \mathrm{cm}^{2}\end{array}$ & $\begin{array}{l}\text { Mouse IgG } \\
\text { antihuman } \\
\text { CD22 (RFB4) } \\
\text { and antihuman } \\
\text { CD25 (RFT5) }\end{array}$ & $\begin{array}{l}\text { mAbs stably attach to CNTs, } \\
\text { mAb-CNTs are well dispersed; } \\
\text { mAb-CNTs bound specifically } \\
\text { to target cells; resulting in } \\
\text { thermal ablation. } P<0.05\end{array}$ \\
\hline MWCNTs $^{59}$ & Kidney cells & $\begin{array}{l}\text { In vitro and } \\
\text { in vivo }\end{array}$ & - & $\begin{array}{l}1064 \mathrm{~nm}, 3 \mathrm{~W} / \mathrm{cm}^{2} \\
\text { (single } 30 \mathrm{~s} \\
\text { treatment) }\end{array}$ & - & $\begin{array}{l}\text { Treatment with MWCNTs } \\
\text { and NIR translated into } \\
\text { inhibition of tumor growth } \\
\text { and long-term survival }\end{array}$ \\
\hline SWCNTs ${ }^{21}$ & HeLa cells & In vitro & $\begin{array}{l}\text { Cervical } \\
\text { cancer }\end{array}$ & $808 \mathrm{~nm}, 3.5 \mathrm{~W} / \mathrm{cm}^{2}$ & $\begin{array}{l}\text { Folate receptor } \\
\text { tumor markers }\end{array}$ & $\begin{array}{l}\text { Selective internalization of } \\
\text { SWCNTs into cells with specific } \\
\text { tumor markers leading to } \\
\text { selective cell death after } \\
\text { NIR radiation }\end{array}$ \\
\hline SWCNTs ${ }^{45}$ & $\begin{array}{l}\text { HER2-expressing } \\
\text { cancer cells }\end{array}$ & In vitro & $\begin{array}{l}\text { Breast } \\
\text { carcinoma }\end{array}$ & $\begin{array}{l}808 \mathrm{~nm}, 5 \mathrm{~W} / \mathrm{cm}^{2} \\
\text { for } 2 \text { minutes }\end{array}$ & $\begin{array}{l}\text { Anti-HER2 } \\
\text { chicken IgY } \\
\text { antibody }\end{array}$ & Increased cytotoxicity \\
\hline
\end{tabular}

Abbreviations: CNT, carbon nanotubes; NIR, near infrared; SWCNTs, single-walled carbon nanotubes; MWCNTs, multiwalled carbon nanotubes; mAb, monoclonal antibody; $\lambda$, wavelength.

\section{CNTs in gene therapy}

As mentioned in the previous section, drug delivery is one of the main applications of CNTs for the treatment of cancer. It has also been discovered that gene delivery, leading to gene therapy and eventually the treatment of cancer, could also be achieved using CNTS. ${ }^{64}$

As a very general definition, gene therapy involves transport of the correct gene by viral or nonviral vectors to the affected area. However, the problem with viral vectors is side effects on the cells, such as inflammation and undesired immune responses. Nonviral vectors, such as liposomes and microparticles, seem to be a safer option, but can also have problems related to a poor pharmacokinetic profile of the administered oligonucleotide and conjugated plasmid DNA.${ }^{64}$ In other words, due to the lack of ability of nonviral vectors to reach and cross the nuclear membrane, the efficiency of gene expression by these vectors is lower compared with viral vectors. ${ }^{22,64,65}$

CNTs seem to represent a very good nonviral vector for gene therapy, because they can cross the cell membrane by an endocytosis process, and also, because of the functionalization of CNTs, the DNA can be transferred without any degradation. ${ }^{66}$ One of the relevant experiments has investigated delivery of siRNA for treatment of tumor cells using functionalized MWCNTs and liposomes. The findings showed that the siRNA delivered via MWCNTs achieved significant inhibition of tumor growth. ${ }^{67}$

\section{Toxicity of CNT}

From much research carried out over recent decades, mankind has seen vital and beneficial changes in science, and one of 

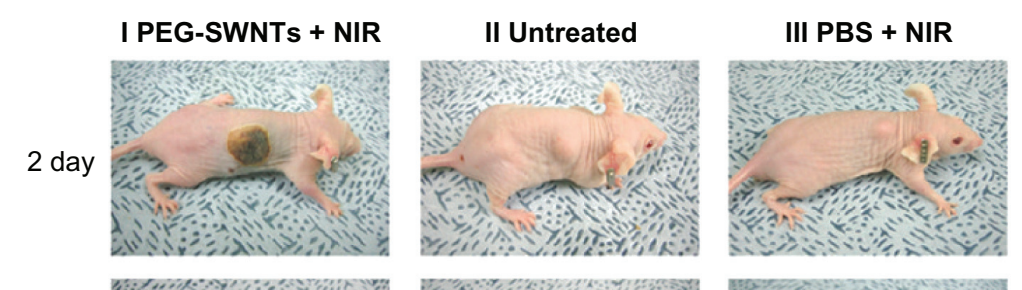

IV PEG-SWNTs

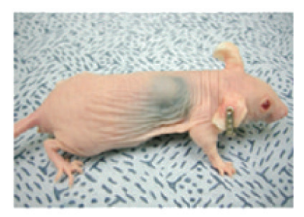

14 day
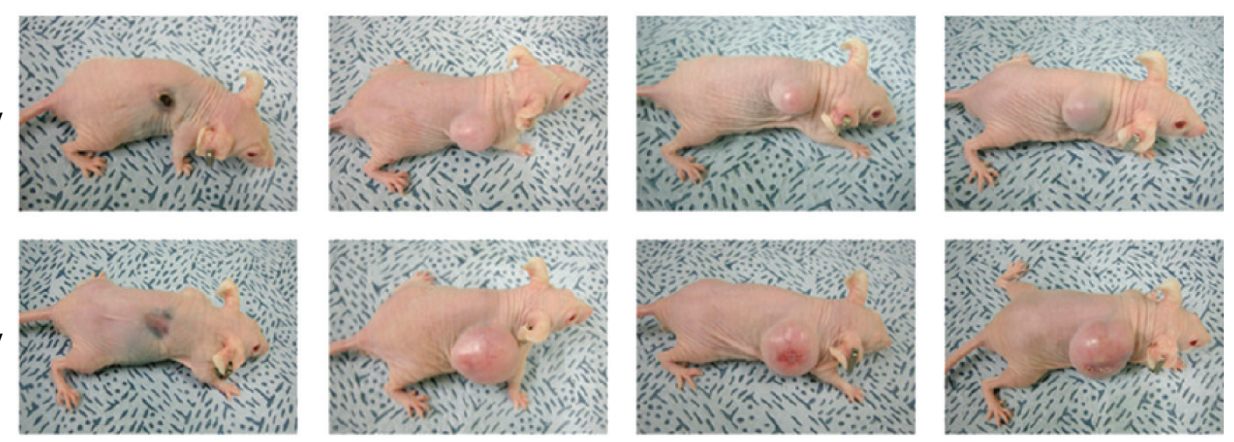

Figure 7 Regression of tumor via thermal ablation. (I) Thermal ablation and subsequent regression of tumor was seen when near infrared was administered with single-walled carbon nanotubes. There was an increase in size of tumor for untreated (II), near infrared alone (III), and carbon nanotubes alone (IV).

Reprinted with permission from ACS Nano, Moon et al, In vivo near-infrared mediated tumor destruction by photothermal effect of carbon nanotubes. Vol. 3, pp. 3707-37I3. Copyright (2009) American Chemical Society.

Abbreviations: PEG, polyethylene glycol; SWNT, single-walled cartoon nanotubes; PBS, phosphate-buffered saline.

the most important of these has been nanotechnology. With its promising applications, nanotechnology has demonstrated to scientists that it has the potential to revolutionize many scientific disciplines. CNT is one of the interesting areas of nanotechnology, due to its many physical and chemical properties mentioned in the previous sections. ${ }^{68}$

There are many benefits of CNTs, but alongside the positives comes a few drawbacks. One of the main concerns for researchers is the fact that nanoparticles, especially CNTs, could be hazardous to human and environmental health. ${ }^{69}$ Therefore, this technology must be monitored in order to assess the potential risk it may hold, and nanotoxicology studies of CNT should be undertaken to investigate the safety of these nanoparticles.

According to different investigations, various factors, such as size of the nanoparticles, and their surface chemistry, dosage, morphology, and chemical components, impact the magnitude of their toxicity. Clearly, the toxicity of CNTs has to be kept at a certain level in order for this technology to be safe. Researchers are always interested in finding new ways in which they can adjust toxicity levels to protect human health.

Various factors impact the toxicity of nanoparticles. It has been shown that, as the particle size decreases, the surface area of the particles increases. This means that there will be more area available for chemical interactions to take place, which would enhance the toxicity of the particles. ${ }^{69,70}$
Various investigations have been carried out on surface chemistry and chemical components of CNTs. These investigations have shown that, despite the biological advantages of these materials, there are also limitations to their biomedical usage because their surfaces are severely contaminated with metal catalysts and amorphous carbon. One of the studies showed that when murine epidermal cells were exposed to unpurified SWCNTS containing 30\% iron, significant dose-dependent activation of transcription factor AP-1 occurred. However, when SWCNTs containing $0.23 \%$ iron were added to the same epidermal cells, no significant changes in AP-1 activation were detected. In other words, when there is a large amount of iron present on the surface of SWCNTs, changes in AP-1 are more easily detectable than when there is hardly any iron present. ${ }^{71}$

The functionalization process refers to the attachment of appropriate molecules to the CNT surface in order to make these materials less toxic and more biocompatible. ${ }^{72}$ Different studies have shown that a high degree of functionalization dramatically reduces the toxicity of CNTs. This is a desirable feature, and needs further research to avoid the problem of toxicity. ${ }^{73}$ The amount of nanoparticles entering the body also has a major impact on toxicity. Results have shown that, regardless of the size of the particles, a high dose of nanoparticles would be toxic to the body.

A number of studies have been done by different research groups on toxicology of CNTs in vitro. The results have suggested that, upon addition of CNTs to cells, 
genes involved in cellular transport, metabolism, cell cycle regulation, stress response, inflammation, and the immune response may be activated. It has also been suggested that addition of CNT could activate genes enabling the cell death program to commence. According to various researchers, upon addition of CNTs to cells, CNTs could enter the cells and be toxic to their functions. ${ }^{74}$ This would have negative implications for the genetic makeup of the cell. Therefore, further research needs to be done in order to reach definitive conclusions.

In another experiment, five concentrations ranging from 0.25 to $100 \mu \mathrm{g} / \mathrm{mL}$ of SWCNTs, MWCNTs, and carbon black were added to RAW 264.7 cells obtained from mice. Results of transmission electron microscopy showed that CNT incubation can eventually induce cell necrosis and apoptosis. Also, 24 hours after addition of CNTs to the RAW 264.7 cells, transmission electron microscopy indicated more phagocytic activity in comparison with normal cells, as shown by changes in nucleus morphology. ${ }^{74}$ However, as mentioned earlier, the functionalization technique used will dramatically attenuate the toxicity of CNTs. ${ }^{72}$

Morphology of the particles also plays a major role in their toxicity. ${ }^{75}$ As an example, the CNTs are known to have a high length to diameter (aspect) ratio, which means that they have the characteristics of both nanoparticles and fibers. Given that CNTs have fibrous characteristics, an extremely high aspect ratio, and low solubility, their behavior can be likened to that of asbestos. ${ }^{69,75}$ Fibers are defined as elongated structures with an aspect ratio $\geq 1: 3$, a length $>5 \mu \mathrm{m}$, and diameter $\leq 3 \mu \mathrm{m}$. The aspect ratios of CNTs have been found to be up to $100 .^{77}$ The apparent similarities between CNTs and asbestos have led to several groups spearheading investigations into the effects of CNT exposure on the respiratory system. Due to the size of the CNTs, these particles can easily become airborne and inhaled. ${ }^{74}$ It has been suggested that widespread distribution of CNTs in the respiratory system could lead to symptoms similar to those that develop after exposure to asbestos. ${ }^{77}$ Inhalation of asbestos fibers is known to induce chronic inflammation, scarring of the lungs (asbestosis), and malignant mesothelioma. ${ }^{68}$ It has been reported that CNTs delivered to the abdominal cavity of mice can induce a response similar to that associated with exposure to asbestos fibers. ${ }^{78}$

In an experiment carried out in the US, mice were intratracheally instilled with a single dose of CNTs $0,0.1$, or $0.5 \mathrm{mg}$, using carbon black as a negative control and quartz as a positive control, and euthanized 7 or 90 days later for histopathological study of the lungs. The results showed that CNTs were much more toxic to the lungs at all concentrations in comparison with carbon black and quartz. The CNTs also induced epithelioid granulomas in a dose-dependent manner, and, in some cases, caused interstitial inflammation. Peribronchial inflammation and, in some cases, necrosis extending into the alveolar septa was also observed.

In a similar experiment carried out in guinea pigs by a group of researchers at Peking University, various concentrations of SWCNTs, MWCNTs, and C60 were added

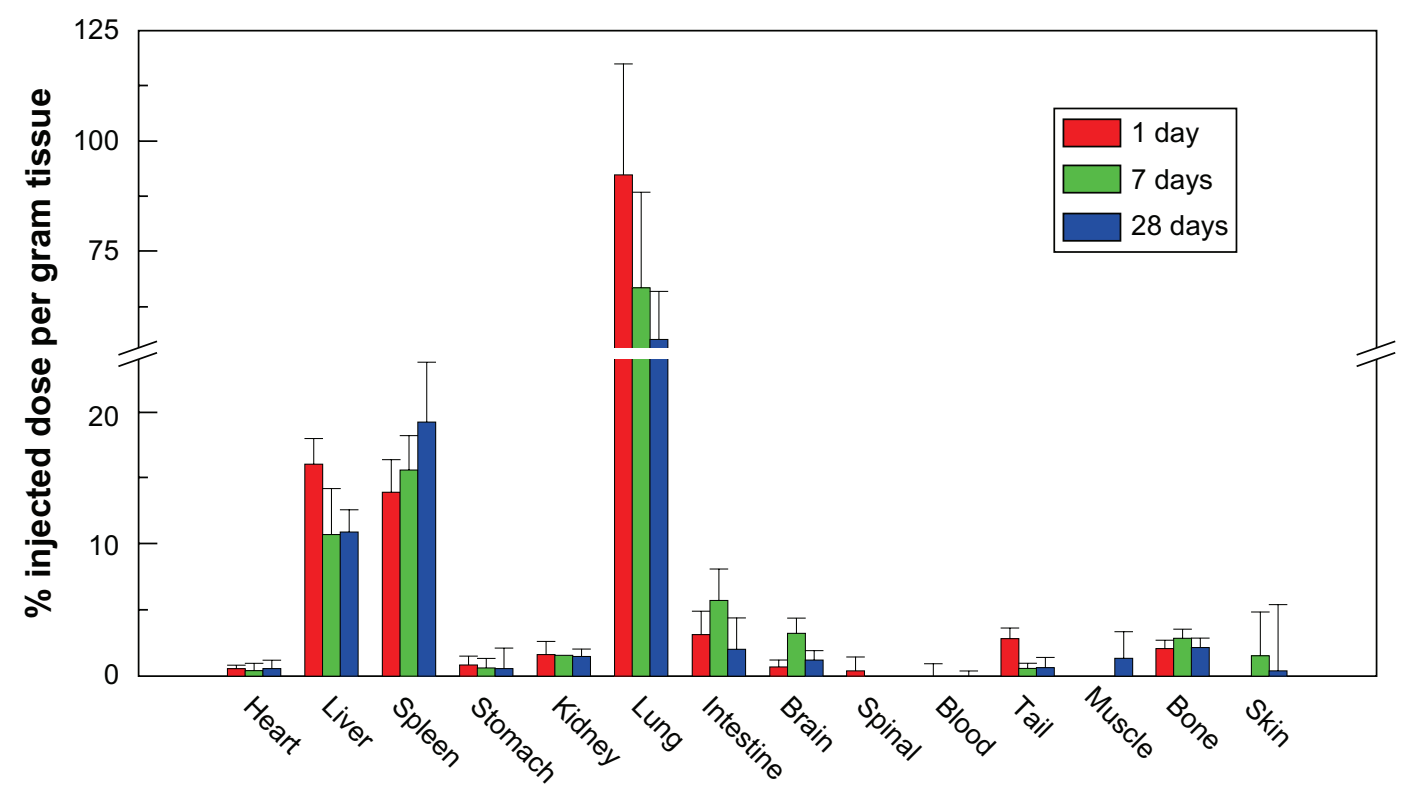

Figure 8 The biodistribution of carbon nanotubes in different organs. A high biodistribution of carbon nanotubes is seen in the liver, spleen, and lung. Reprinted with permission from J Phys Chem B, Yang et al, Biodistribution of pristine single-walled carbon nanotubes in vivo. Vol. II, Pp. I776I-I7764. Copyright (2007) American Chemical Society. 
to alveolar macrophages. Cytotoxicity testing showed that, as the CNTs dose increased, more cells became affected by toxicity, demonstrating that necrosis occurs more frequently with increasing CNT dosage. SWCNTs also produced greater toxicity in comparison with MWCNTs at the same doses. Unlike MWCNTs and SWCNTs, C60 did not show any toxicity. ${ }^{79}$

Once nanoparticles are inhaled, they deposit on the surface of the lungs and interact with lung surfactants. Upon deposition, they either penetrate the lung tissues or get phagocytosed. ${ }^{75}$ CNTs have been associated with defective phagocytosis, leading to chronic inflammation, ${ }^{80}$ most likely because of their high aspect ratio, which is a property they have in common with asbestos. ${ }^{81}$

In another experiment, $50 \mu \mathrm{g}$ of nonfunctionalized MWCNTs of different lengths was dispersed in saline with bovine serum albumin and injected into normal mice intraperitoneally. MWCNTs with lengths $>20 \mu \mathrm{m}$ accumulated in significant amounts in the diaphragmatic mesothelium, unlike entangled nanotube aggregates or negative control-containing compounds with low aspect ratios and not needle-shaped. This result would indicate that because the long-length CNTs could not be engulfed by macrophages, they would have a higher risk of toxicity. ${ }^{78} \mathrm{~A}$ major question that remains to be answered is the fate of CNTs in biological systems (Figure 8). There is evidence to suggest that the clearance rate of CNTs in the body is rather low, which could lead to the formation of granulomas. ${ }^{82}$

\section{Conclusion and future directions}

The advent of nanotechnology in biological systems heralds a new chapter in the field of regenerative and translational medicine. ${ }^{83}$ The novel properties of CNTs allow them to be multifunctional therapeutic agents in cancer treatment. However, one major hurdle that needs to be addressed is the issue of toxicity. It is highly probable that functionalizing CNTs would allow them to be biocompatible for clinical applications. Despite this, the advances made in both in vivo and in vitro animal models, however small, are very real and are of great significance in our understanding of the biological effects of nanoparticles. Therefore, more rigorous in vitro and in vivo testing is not only worth pursuing, but very necessary.

\section{Acknowledgment}

We would like to acknowledge the financial support of The Sebba Trust, UK for development of CNT and QD for detection and treatment of breast cancer.

\section{Disclosure}

The authors report no conflicts of interest in this work.

\section{References}

1. Westlake S, Cooper N. Cancer incidence and mortality: Trends in the United Kingdom and constituent countries, 1993 to 2004. Health Stat Q. 2008;38:33-46.

2. Utreja P, Jain S, Tiwary AK. Novel drug delivery systems for sustained and targeted delivery of anti-cancer drugs: Current status and future prospects. Curr Drug Deliv. 2010;7:152-161.

3. Batra R, Davies JN, Wheatley D. Extensive arterial and venous thrombo-embolism with chemotherapy for testicular cancer: A case report. Cases J. 2009;2:9082.

4. Dhar S, Liu Z, Thomale J, Dai H, Lippard SJ. Targeted single-wall carbon nanotube-mediated Pt(IV) prodrug delivery using folate as a homing device. J Am Chem Soc. 2008;130:11467-11476.

5. Liu Z, Chen K, Davis C, et al. Drug delivery with carbon nanotubes for in vivo cancer treatment. Cancer Res. 2008;68:6652-6660.

6. Ghanbari H, de Mel A, Seifalian AM. Cardiovascular application of polyhedral oligomeric silsesquioxane nanomaterials: A glimpse into prospective horizons. Int J Nanomedicine. 2011;6:775-786.

7. Jamieson T, Bakhshi R, Petrova D, Pocock R, Imani M, Seifalian AM. Biological applications of quantum dots. Biomaterials. 2007;28: 4717-4732.

8. Tan A, De La Pena H, Seifalian AM. The application of exosomes as a nanoscale cancer vaccine. Int J Nanomedicine. 2010;5:889-900.

9. Chang TM, Prakash S. Procedures for microencapsulation of enzymes, cells and genetically engineered microorganisms. Mol Biotechnol. 2001;17:249-260.

10. Sahoo NG, Bao H, Pan Y, et al. Functionalized carbon nanomaterials as nanocarriers for loading and delivery of a poorly water-soluble anticancer drug: A comparative study. Chem Commun (Camb). 2011;47: 5235-5237.

11. Lamprecht C, Liashkovich I, Neves V, et al. AFM imaging of functionalized carbon nanotubes on biological membranes. Nanotechnology. 2009;20:434001.

12. Beg S, Rizwan M, Sheikh AM, Hasnain MS, Anwer K, Kohli K. Advancement in carbon nanotubes: Basics, biomedical applications and toxicity. J Pharm Pharmacol. 2011;63:141-163.

13. Raffa V, Ciofani G, Vittorio O, Riggio C, Cuschieri A. Physicochemical properties affecting cellular uptake of carbon nanotubes. Nanomedicine (Lond). 2010;5:89-97.

14. Porter AE, Gass M, Muller K, Skepper JN, Midgley PA, Welland M. Direct imaging of single-walled carbon nanotubes in cells. Nat Nanotechnol. 2007;2:713-717.

15. Bianco A, Kostarelos K, Prato M. Applications of carbon nanotubes in drug delivery. Curr Opin Chem Biol. 2005;9:674-679.

16. Pantarotto D, Briand JP, Prato M, Bianco A. Translocation of bioactive peptides across cell membranes by carbon nanotubes. Chem Commun (Camb) 2004;1:16-17.

17. Campbell JF, Tessmer I, Thorp HH, Erie DA. Atomic force microscopy studies of DNA-wrapped carbon nanotube structure and binding to quantum dots. J Am Chem Soc 2008;130:10648-10655.

18. Kam NW, Dai H. Carbon nanotubes as intracellular protein transporters: Generality and biological functionality. $\mathrm{J}$ Am Chem Soc. 2005;127:6021-6026

19. Arsawang U, Saengsawang O, Rungrotmongkol T, et al. How do carbon nanotubes serve as carriers for gemcitabine transport in a drug delivery system? J Mol Graph Model. 2011;29:591-596.

20. Shi Kam NW, Jessop TC, Wender PA, Dai H. Nanotube molecular transporters: Internalization of carbon nanotube-protein conjugates into mammalian cells. J Am Chem Soc. 2004;126:6850-6851.

21. Kam NW, O'Connell M, Wisdom JA, Dai H. Carbon nanotubes as multifunctional biological transporters and near-infrared agents for selective cancer cell destruction. Proc Natl Acad Sci U SA. 2005;102:11600-11605. 
22. Klumpp C, Kostarelos K, Prato M, Bianco A. Functionalized carbon nanotubes as emerging nanovectors for the delivery of therapeutics. Biochim Biophys Acta. 2006;1758:404-412.

23. Bekyarova E, Ni Y, Malarkey EB, et al. Applications of carbon nanotubes in biotechnology and biomedicine. J Biomed Nanotechnol. 2005;1:3-17.

24. Danailov D, Keblinski P, Nayak S, Ajayan PM. Bending properties of carbon nanotubes encapsulating solid nanowires. J Nanosci Nanotechnol. 2002;2:503-507.

25. Ebbesen TW, Ajayan PM. Large-scale synthesis of carbon nanotubes. Nature. 1992;358:220-222.

26. Feazell RP, Nakayama-Ratchford N, Dai H, Lippard SJ. Soluble singlewalled carbon nanotubes as longboat delivery systems for platinum (IV) anticancer drug design. J Am Chem Soc. 2007;129:8438-8439.

27. Liu Z, Davis C, Cai W, He L, Chen X, Dai H. Circulation and long-term fate of functionalized, biocompatible single-walled carbon nanotubes in mice probed by Raman spectroscopy. Proc Natl Acad Sci U S A. 2008;105:1410-1415.

28. Hartschuh A, Pedrosa HN, Novotny L, Krauss TD. Simultaneous fluorescence and Raman scattering from single carbon nanotubes. Science. 2003;301:1354-1356

29. Hirsch LR, Stafford RJ, Bankson JA, et al. Nanoshell-mediated nearinfrared thermal therapy of tumors under magnetic resonance guidance. Proc Natl Acad Sci U S A. 2003;100:13549-13554.

30. Prato M, Kostarelos K, Bianco A. Functionalized carbon nanotubes in drug design and discovery. Acc Chem Res. 2008;41:60-68.

31. Liu Z, Tabakman SM, Chen Z, Dai H. Preparation of carbon nanotube bioconjugates for biomedical applications. Nat Protoc. 2009;4: 1372-1382.

32. Rosca ID, Watari F, Uo M, Akaska T. Oxidation of multiwalled carbon nanotubes by nitric acid. Carbon. 2005;43:3124-3131.

33. Liu Z, Sun X, Nakayama-Ratchford N, Dai H. Supramolecular chemistry on water-soluble carbon nanotubes for drug loading and delivery. $A C S$ Nano. 2007;1:50-56.

34. Niyogi S, Hamon MA, Hu H, et al. Chemistry of single-walled carbon nanotubes. Acc Chem Res. 2002;35:1105-1113.

35. Hampel S, Kunze D, Haase D, et al. Carbon nanotubes filled with a chemotherapeutic agent: A nanocarrier mediates inhibition of tumor cell growth. Nanomedicine (Lond). 2008;3:175-182.

36. Jin H, Heller DA, Strano MS. Single-particle tracking of endocytosis and exocytosis of single-walled carbon nanotubes in NIH-3T3 cells. Nano Lett. 2008;8:1577-1585.

37. Wu W, Li R, Bian X, et al. Covalently combining carbon nanotubes with anticancer agent: Preparation and antitumor activity. ACS Nano. 2009;3:2740-2750.

38. LiY, Cousins BG, Ulijn RV, Kinloch IA. A study of the dynamic interaction of surfactants with graphite and carbon nanotubes using Fmoc-amino acids as a model system. Langmuir. 2009;25:11760-11767.

39. $\mathrm{Xu} \mathrm{H}$, Meng J, Kong $\mathrm{H}$. What are carbon nanotube roles in anti-tumor therapies? Science in China. 2010;53:2250-2256.

40. Deutsch HM, Glinski JA, Hernandez M, et al. Synthesis of congeners and prodrugs. 3. Water-soluble prodrugs of taxol with potent antitumor activity. J Med Chem. 1989;32:788-792.

41. Gottesman MM, Fojo T, Bates SE. Multidrug resistance in cancer: Role of ATP-dependent transporters. Nat Rev Cancer. 2002;2:48-58.

42. li-Boucetta H, Al-Jamal KT, McCarthy D, Prato M, Bianco A, Kostarelos K. Multiwalled carbon nanotube-doxorubicin supramolecular complexes for cancer therapeutics. Chem Commun (Camb). 2008;4:459-461.

43. Liu Z, Fan AC, Rakhra K, et al. Supramolecular stacking of doxorubicin on carbon nanotubes for in vivo cancer therapy. Angew Chem Int Ed Eng. 2009;48:7668-7672.

44. Arlt M, Haase D, Hampel S, et al. Delivery of carboplatin by carbonbased nanocontainers mediates increased cancer cell death. Nanotechnology. 2010;21:335101.

45. Xiao Y, Gao XG, Taratula O, et al. Anti-HER2 IgY antibody-functionalized single-walled carbon nanotubes for detection and selective destruction of breast cancer cells. BMC Cancer. 2009;95:351.
46. Prajapati VK, Awasthi K, Gautam S, et al. Targeted killing of Leishmania donovani in vivo and in vitro with amphotericin B attached to functionalized carbon nanotubes. J Antimicrob Chemother. 2011;66:874-879.

47. Ashcroft JM, Tsyboulski DA, Hartman KB, et al. Fullerene (C60) immunoconjugates: Interaction of water-soluble C60 derivatives with the murine anti-gp240 melanoma antibody. Chem Commun (Camb). 2006;28:3004-3006.

48. Shi DL, Cho HS, Huth C, et al. Conjugation of quantum dots and Fe3O4 on carbon nanotubes for medical diagnosis and treatment. Appl Phys Lett. 2009;95:223702.

49. Antonelli A, Serafini S, Menotta M, et al. Improved cellular uptake of functionalized single-walled carbon nanotubes. Nanotechnology. 2010;21:425101.

50. Kang B, Chang S, Dai Y, Yu D, Chen D. Cell response to carbon nanotubes: Size-dependent intracellular uptake mechanism and subcellular fate. Small. 2010;6:2362-2366.

51. Samori C, li-Boucetta H, Sainz R, et al. Enhanced anticancer activity of multi-walled carbon nanotube-methotrexate conjugates using cleavable linkers. Chem Commun (Camb). 2010;46:1494-1496.

52. Kam NW, Liu Z, Dai H. Functionalization of carbon nanotubes via cleavable disulfide bonds for efficient intracellular delivery of siRNA and potent gene silencing. J Am Chem Soc. 2005;127: 12492-12493.

53. Chen X, Chen H, Tripisciano C, et al. Carbon-nanotube-based stimuli-responsive controlled-release system. Chemistry. 2011;17:4454-4459.

54. O’Neal DP, Hirsch LR, Halas NJ, Payne JD, West JL. Photo-thermal tumor ablation in mice using near infrared-absorbing nanoparticles. Cancer Lett. 2004;209:171-176.

55. Zavaleta C, de la Zerda A, Liu Z, et al. Noninvasive Raman spectroscopy in living mice for evaluation of tumor targeting with carbon nanotubes. Nano Lett. 2008;8:2800-2805.

56. Zharov VP, Galitovskaya EN, Johnson C, Kelly T. Synergistic enhancement of selective nanophotothermolysis with gold nanoclusters: Potential for cancer therapy. Lasers Surg Med. 2005;37:219-226.

57. Biris AS, Boldor D, Palmer J, et al. Nanophotothermolysis of multiple scattered cancer cells with carbon nanotubes guided by time-resolved infrared thermal imaging. J Biomed Opt. 2009;14:021007.

58. Imamura J, Tateishi R, Shiina $\mathrm{S}$, et al. Neoplastic seeding after radiofrequency ablation for hepatocellular carcinoma. Am J Gastroenterol. 2008;103:3057-3062.

59. Burke A, Ding X, Singh R, et al. Long-term survival following a single treatment of kidney tumors with multiwalled carbon nanotubes and near-infrared radiation. Proc Natl Acad Sci USA. 2009;106: 12897-12902

60. Gannon CJ, Cherukuri P, Yakobson BI, et al. Carbon nanotube-enhanced thermal destruction of cancer cells in a noninvasive radiofrequency field. Cancer. 2007;110:2654-2665.

61. Moon HK, Lee SH, Choi HC. In vivo near-infrared mediated tumor destruction by photothermal effect of carbon nanotubes. ACS Nano. 2009;3:3707-3713

62. Liu Z, Cai W, He L, et al. In vivo biodistribution and highly efficient tumour targeting of carbon nanotubes in mice. Nat Nanotechnol. 2007;2:47-52.

63. Klingeler R, Hampel S, Buchner B. Carbon nanotube based biomedical agents for heating, temperature sensoring and drug delivery. Int $J$ Hyperthermia. 2008;24:496-505.

64. Osada K, Christie RJ, Kataoka K. Polymeric micelles from poly(ethylene glycol)-poly(amino acid) block copolymer for drug and gene delivery. $J$ R Soc Interface. 2009;6 Suppl 3:S325-329.

65. de Mel A, Murad F, Seifalian AM. Nitric oxide: A guardian for vascular grafts? Chem Rev. 2011;111:5742-5767.

66. Cai D, Mataraza JM, Qin ZH, et al. Highly efficient molecular delivery into mammalian cells using carbon nanotube spearing. Nat Methods. 2005;2:449-454.

67. Podesta JE, Al-Jamal KT, Herrero MA, et al. Antitumor activity and prolonged survival by carbon-nanotube-mediated therapeutic siRNA silencing in a human lung xenograft model. Small. 2009;5:1176-1185. 
68. Kim JS, Song KS, Lee JH, Yu IJ. Evaluation of biocompatible dispersants for carbon nanotube toxicity tests. Arch Toxicol. 2011. [Epub ahead of print.]

69. Berhanu D, Dybowska A, Misra SK, et al. Characterisation of carbon nanotubes in the context of toxicity studies. Environ Health. 2009;8 Suppl 1:S3.

70. Ai J, Biazar E, Jafarpour M, et al. Nanotoxicology and nanoparticle safety in biomedical designs. Int J Nanomedicine. 2011;6:1117-1127.

71. Park EJ, Roh J, Kim SN, et al. A single intratracheal instillation of singlewalled carbon nanotubes induced early lung fibrosis and subchronic tissue damage in mice. Arch Toxicol. 2011;85:1121-1131.

72. Fei B, Lu HF, Hu ZG, Xin JH. Solubilization, purification and functionalization of carbon nanotubes using polyoxometalate. Nanotechnology. 2006;17:1589-1593.

73. Coccini T, Roda E, Sarigiannis DA, et al. Effects of water-soluble functionalized multi-walled carbon nanotubes examined by different cytotoxicity methods in human astrocyte D384 and lung A549 cells. Toxicology. 2010;269:41-53.

74. Di Giorgio ML, Bucchianico SD, Ragnelli AM, Aimola P, Santucci S, Poma A. Effects of single and multi walled carbon nanotubes on macrophages: Cyto and genotoxicity and electron microscopy. Mutat Res. 2011;722:20-31

75. Wang R, Mikoryak C, Li S, et al. Cytotoxicity screening of single-walled carbon nanotubes: Detection and removal of cytotoxic contaminants from carboxylated carbon nanotubes. Mol Pharm. 2011;8:1351-1361.

76. Maynard AD, Baron PA, Foley M, Shvedova AA, Kisin ER, Castranova V. Exposure to carbon nanotube material: Aerosol release during the handling of unrefined single-walled carbon nanotube material. J Toxicol Environ Health A. 2004;67:87-107.

77. Poland CA, Duffin R, Kinloch I, et al. Carbon nanotubes introduced into the abdominal cavity of mice show asbestos-like pathogenicity in a pilot study. Nat Nanotechnol. 2008;3:423-428.

78. Kostarelos K. The long and short of carbon nanotube toxicity. Nat Biotechnol. 2008;26:774-776.

79. Lam CW, James JT, McCluskey R, Hunter RL. Pulmonary toxicity of single-wall carbon nanotubes in mice 7 and 90 days after intratracheal instillation. Toxicol Sci. 2004;77:126-134.

80. Brown DM, Kinloch IA, Bangert U, et al. An in vitro study of the potential of carbon nanotubes and nanofibres to induce inflammatory mediators and frustrated phagocytosis. Carbon. 2007;45:1743-1756.

81. Donaldson K, Aitken R, Tran L, et al. Carbon nanotubes: A review of their properties in relation to pulmonary toxicology and workplace safety. Toxicol Sci. 2006;92:5-22.
82. Yang ST, Guo W, Lin Y, et al. Biodistribution of pristine single-walled carbon nanotubes in vivo. J Phys Chem B. 2007;11:17761-17764.

83. Ghanbari H, Cousins BG, Seifalian AM. A nanocage for nanomedicine: Polyhedral oligomeric silsesquioxane (POSS). Macromol Rapid Commun. 2011;32:1032-1046.

84. Heister E, Lamprecht C, Neves V, et al. Higher dispersion efficacy of functionalized carbon nanotubes in chemical and biological environments. ACS Nano. 2010;4:2615-2626.

85. Chen CC, Chen CF, Chen CM, Chuang FT. Modification of multi-walled carbon nanotubes by microwave digestion method as electrocatalyst supports for direct methanol fuel cell applications. Electrochem Commun. 2007;9:159-163.

86. Zhu N, Gao H, Xu Q, Lin Y, Su L, Mao L. Sensitive impedimetric DNA biosensor with poly(amidoamine) dendrimer covalently attached onto carbon nanotube electronic transducers as the tether for surface confinement of probe DNA. Biosens Bioelectron. 2010;25:1498-1503.

87. Bhirde AA, Sousa AA, Patel V, et al. Imaging the distribution of individual platinum-based anticancer drug molecules attached to single-wall carbon nanotubes. Nanomedicine (Lond). 2009;4:763-772.

88. Wang YB, Iqbal Z, Mitra S. Microwave-induced rapid chemical functionalization of single-walled carbon nanotubes. Carbon. 2005;43:1015-1020

89. Beuvelot J, Bergeret C, Mallet R, et al. In vitro calcification of chemically functionalized carbon nanotubes. Acta Biomater. 2010;6:4110-4117.

90. Li R, Wu R, Zhao L, Wu M, Yang L, Zou H. P-glycoprotein antibody functionalized carbon nanotube overcomes the multidrug resistance of human leukemia cells. ACS Nano. 2010;4:1399-1408.

91. Taghdisi SM, Lavaee P, Ramezani M, Abnous K. Reversible targeting and controlled release delivery of daunorubicin to cancer cells by aptamerwrapped carbon nanotubes. Eur J Pharm Biopharm. 2011;77:200-206.

92. Hong SY, Tobias G, Al-Jamal KT, et al. Filled and glycosylated carbon nanotubes for in vivo radioemitter localization and imaging. Nat Mater. 2010;9:485-490.

93. Chakravarty P, Marches R, Zimmerman NS, et al. Thermal ablation of tumor cells with antibody-functionalized single-walled carbon nanotubes. Proc Natl Acad Sci U S A. 2008;105:8697-8702.

94. Boldor D, Gerbo NM, Monroe WT, Palmer JH, Li ZR, Biris AS. Temperature measurement of carbon nanotubes using infrared thermography. Chem Mater. 2008;20:4011-4016.

95. Marches R, Chakravarty P, Musselman IH, et al. Specific thermal ablation of tumor cells using single-walled carbon nanotubes targeted by covalently-coupled monoclonal antibodies. Int J Cancer. 2009;125:2970-2977.
International Journal of Nanomedicine

\section{Publish your work in this journal}

The International Journal of Nanomedicine is an international, peerreviewed journal focusing on the application of nanotechnology in diagnostics, therapeutics, and drug delivery systems throughout the biomedical field. This journal is indexed on PubMed Central,

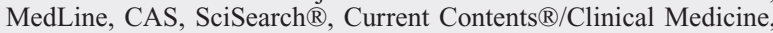

\section{Dovepress}

Journal Citation Reports/Science Edition, EMBase, Scopus and the Elsevier Bibliographic databases. The manuscript management system is completely online and includes a very quick and fair peer-review system, which is all easy to use. Visit http://www.dovepress.com/ testimonials.php to read real quotes from published authors. 